\title{
Biological control opportunities of ragweed are predicted to decrease with climate change in East Asia
}

\author{
Yan Sun $^{1 *}$, Zhongshi Zhou ${ }^{2}$, Rui Wang ${ }^{2}$, Heinz Müller-Schärer ${ }^{3}$ \\ 1 Plant Evolutionary Ecology, University of Tübingen, 72076 Tübingen, Germany \\ 2 State Key Laboratory for Biology of Plant Diseases and Insect Pests, Institute of Plant Protection, Chinese Academy of \\ Agricultural Sciences, Beijing 100193, China \\ 3 Department of Biology/Ecology \& Evolution, University of Fribourg, 1700 Fribourg, Switzerland
}

\begin{abstract}
The control of invasive alien plants (IAP) that jeopardize our ecosystems and economy constitutes a significant challenge for natural resource management. Classical biological control referring to the introduction of specialist antagonists from the native range has proven to be a highly cost-effective management tool against IAP. A critical issue in biological control research is to guide informed decision-making on the potential spread and distribution and thus impact of biological control candidates, especially under climate change. Here we propose a biogeographic modeling approach to predict the cover of the suitable area of a plant invader in East Asia (EA) by two biological control agents and their combinations. Our study system is Ambrosia artemisiifolia, native to North America and invasive worldwide, and two North American biological control agents, Ophraella communa and Epiblema strenuana that were accidentally and deliberately introduced into East Asia (EA) in the late 20th century, respectively. Specifically, we ask: (1) what percentage of the suitable A. artemisiifolia area is also suitable for the two agents in EA, and (2) which part of the suitable $A$. artemisiifolia area in EA is likely to remain uncovered by these two agents, both under current and future climatic scenarios; and (3) which particular biotypes would be needed to fill in the yet uncovered part of the suitable A. artemisiifolia range in EA? For this, we simultaneously modelled the species distributions based on worldwide occurrences and important bioclimatic variables for the target invasive plant and its two biological control agents. Ordination techniques were used to explore climatic constraints of each species and to perform niche overlap and similarity tests with A. artemisiifolia between its native North American and introduced EA range. Our results show that $O$. communa has a larger overlap with the geographic range of $A$. artemisiifolia than E. strenuana, both under current and future climatic scenarios. Importantly, climate change is expected to reduce the total geographic overlap of A. artemisiifolia by the two agents combined, with a higher reduction by $O$. communa than by E. strenuana. Our analyses also identified for which abiotic conditions to select in order to develop climatically adapted strains for particular regions, where A. artemisiifolia is presently unlikely to be covered.
\end{abstract}

Key words: biological invasions; Epiblema strenuana; Ophraella communa; biological control; niche overlap; species distribution

\section{Introduction}

Biological invasions by alien plants, i.e. plants that are introduced intentionally or unintentionally outside their native geographical range, are among the most important drivers of global change and can have devastating impacts on ecosystems and economy (Vilà et al, 2011). Management and control of invasive alien plants have thus become a great challenge for ecologists, conservation biologists and environmental practitioners involved in natural resource management (Walker \& Steffen, 1997; Kettenring \& Adams, 2011).
In this respect, 'classical' biological control by releasing specialist natural antagonists from the invaders' native range has been a most successful management tool to reduce the abundance of invasive plants, owing to its cost-effectiveness and relatively high environmental safety (Müller-Schärer \& Schaffner, 2008; Winston et al, 2014; Seastedt, 2015).

Species distribution models (SDMs) relating geo-located observations of occurrence data to a variety of environmental data sets that contribute to a species' survival and propagation allow identifying ecological characteristics that define the species range and 
distribution (Guisan \& Zimmermann, 2000). Furthermore, SDMs are also a very useful tool for predicting the response of species distributions to climate change (Peterson, 2011). Recently, SDMs have been increasingly used to predict the spatial extent of invasions and identify at-risk habitats under current climate and on-going environmental change (Peterson, 2003). In analogy, SDMs also provided a most helpful tool to predict most suitable ranges of biological control agents in the introduced ranges (Sun et al, 2017). It further allowed to identify both suitable collection locations of biological control agents in the home range (Mukherjee et al, 2011) and of release sites in the introduced area, as climate clearly influences their establishment and performance due to underlying biophysical factors (Hoelmer \& Kirk, 2005). Indeed, biological control agent with an optimal climatic match between home and release locations were found to better establish and become more efficient than agents with a less good match (Goolsby et al, 2005). Important complementary information from species occurrences that are relevant for invasion management can be deduced from ordination techniques that allow for direct comparisons of species-environment relationships in the environmental space (Broennimann et al, 2012).

Climate change (IPCC, 2013) is expected to significantly impact the distribution of species and the resource dynamics of ecosystems, with particular importance for biological invaders and associated consumers used for biological control (Theoharides \& Dukes, 2007; Walther et al, 2009). Climatic factors are also of major importance in determining the outcome of species interactions for species distributions and thus also for biological control programmes (Messenger \& Van den Bosch, 1971), as plants and arthropods might react differently to climate change (Hannah et al, 2002; Gillson et al, 2013). An understanding of the impact of future climate variability on invasive alien species and on their biological control agents is thus of fundamental importance for predicting sustainable biological control management. For this, bioclimatic models provide a cost-effective approach that further allows considering both present and future climatic conditions.

Common ragweed, Ambrosia artemisiifolia (Asteraceae), is an annual wind-pollinated monoecious weed native to North America and Mexico, and was accidentally introduced to many parts of the world, including Asia, South America, Australia and Europe. Both in its native and introduced ranges, A. artemisiifolia is causing great damage to the society due to its highly allergenic pollen, and because it grows as a weed in many crops, where it is hard to control (Wan et al, 2005; Essl et al, 2015). In China, pollen aller- gens have been found in 2-3\% of the human population, where $A$. artemisiifolia occurs and resulting health cost have been estimated to 1.4 billion CHY per year (Zhou et al, 2015). Ambrosia artemisiifolia was established in Japan more than 100 years ago, and became widely distributed throughout the Japanese islands by 1950s (Fukano \& Yahara, 2012). In China, A. artemisiifolia has been reported since the 1930s and has been considered as a harmful weed in various crops since 1997 (Wan et al, 1993). Besides being linked to agricultural land, A. artemisiifolia is also widely distributed along linear transport structures, such as railways, roads and rivers both in China (Wan et al, 1993) and Japan (Hisauchi, 1950). The ability of A. artemisiifolia to grow side branches after partial control by cutting and herbicides and its high proliferation rate renders its management challenging (Wan et al, 2005; Essl et al, 2015). Herbicides and mechanical control (i.e. uprooting, cutting and ploughing) treatments are well suited for the short-term management of small emerging populations (Essl et al, 2015). In crop situations, herbicides for biomass reduction of A. artemisiifolia are available; yet, flowering, pollen production and seed set can only rarely be prevented (Gerber et al, 2011).

A promising management option for long-term and sustainable control is classical biological control. This option has proven to be most successful against $A$. artemisiifolia in China by using Ophraella communa LeSage (Coleoptera: Chrysomelidae) and Epiblema strenuana Walker (Lepidoptera: Tortricidae) (Zhou et al, 2011b). Both species are native to North America. Ophraella communa is an oligophagous leaf beetle with A. artemisiifolia as its preferred host plant (LeSage, 1986; Futuyma \& McCafferty, 1990; Palmer \& Goeden, 1991). In East Asia, it was accidentally introduced and first discovered in Chiba Prefecture (eastern Japan) in 1996, from where it rapidly spread across the main Japanese islands (Yamazaki et al, 2000; Moriya \& Shiyake, 2001). In China it was first recorded in 1999 (Zhou et al, 2014). Under favorable environmental conditions, O. communa can reach 4-7 generations per year, which allows it to build up high local densities during the second half of the A. artemisiifolia growing season. This beetle can cause complete defoliation and death of A. artemisiifolia under both experimental and field conditions (Palmer \& Goeden, 1991; Zhou et al, 2014). It is currently used as the most efficient and successful biological control agent against $A$. artemisiifolia in China and is also reported to cause heavy damage to A. artemisiifolia in Japan (Yamazaki et al, 2000; Fukano \& Doi, 2013). Earlier studies indicated that $O$. communa is mainly adapted to subtropical conditions (Zhou et al, 2010). Recent studies in China attempted to select for $O$. 
communa strains that can occur and reach higher numbers of generations at higher latitudes where temperatures during the coldest months of the year are significantly lower (Zhou et al, 2011a, 2013). In Japan and South Korea, the beetle so far has not yet been deliberately redistributed (Winston et al, 2014).

Epiblema strenuana is a stem mining and gall-inducing moth producing fusiform galls mainly on lateral branches of mature Ambrosia plants, with 3-4 generations per year under favorable conditions (Ma et al, 2008). It has been reported to complete 2-3 generations in Northern China and 4-5 generations in Central China (Zhou et al, 2014). It was deliberately introduced from Mexico to Australia in 1982 against Parthenium hysterophorus L., and later became established and subsequently also widely distributed on $A$. artemisiifolia (McFadyen, 1992). The moth was deliberately introduced from Australia to China in 1990 to control A. artemisiifolia, released in 1993 after additional host specificity tests and subsequently became widely established in southern China (Wan et al, 2005).

First mass releases of these two biological control agent were made in 1993 in Yueyang, Hunan, where they controlled more than $2,000 \mathrm{~km}^{2}$ of A. artemisiifolia infestations in Hunan Province in 1999 and subsequently also spread to Hubei and Jiangxi provinces ( $\mathrm{Li}$ et al, 1999). In southern China, O. communa and $E$. strenuana coexist in many areas invaded by $A$. artemisiifolia and are recommended to be used together to successfully control $A$. artemisiifolia in China (Zhou et al, 2014).

Sun et al (2017) recently constructed, for the first time, species distribution models based on worldwide occurrences and important bioclimatic variables simultaneously for a plant invader and its biological control candidates in view of selecting candidates that potentially cover a large range of the target invader. Their study was performed for A. artemisiifolia and six biological control candidates in view of assessing their suitability to control A. artemisiifolia in Europe. The main objective of the present investigation is to predict the overlap of suitable A. artemisiifolia areas by the two biological control agents in East Asia (EA) both for current and future climatic conditions. More specifically, we asked (1) what percentage of the suitable A. artemisiifolia range in EA is also suitable for the two agents; (2) which part of the suitable A. artemisiifolia area in EA is likely to remain uncovered by these two agents; and (3) for which abiotic conditions to select for in order to develop climatically adapted strains for particular regions, where $A$. artemisiifolia is presently unlikely to be covered. Besides SDMs, we also performed Principal Component Analyses (PCA) of both the North American and East Asian climatic niche of $A$. artemisiifolia and of the available occurrences of two biological control agents.

\section{Materials \& Methods}

\section{Species occurrences and bioclimatic data}

We collected all available occurrence data from the literature for A. artemisiifolia and the two biological control agents $O$. communa and $E$. strenuana worldwide. Geo-referenced occurrence records of the three species were downloaded from online resources: the Global Biodiversity Information Facility online database (GBIF; http://www.gbif.org), the Southwest Environmental Information Network (SEINet; http://swbiodiversity.org), the Barcode of Life Data Systems (BOLD; http://www.boldsystems.org/), and the Berkeley Ecoinformatics Engine (Ecoengine; https://ecoengine.berkeley.edu/). The many additional sources for occurrences of A. artemisiifolia and the two insect species are given in the Supporting Information of Sun et al (2017).

We used WORLDCLIM climate data available at http://www.worldclim.org (developed by Hijmans et al, 2005) with 19 variables (Appendix 1) at $5 \mathrm{~min}$ utes spatial resolution ( $\sim 10 \mathrm{~km}$ close to the equator) to derive a set of meaningful predictors that are considered critical to the plant or insect physiological functions for development and survival of each of our species. We chose important variables for each species under the current climatic condition and four future scenarios based on Sun et al (2017). For the four 'future' scenario projections for the 2050 time slice (averages for 2041-2060), we adopted two general circulation models (GCMs: HadGEM2-AO and IPSL-CM5A-LR) under two representative concentration pathways, RCP26 and RCP85 (Giorgetta et al, 2013). Data were developed for the Coupled Model Intercomparison Project Phase 5 (CMIP5, IPCC Fifth Assessment, IPCC, 2013) and downloaded from http://www.worldclim.org at a spatial resolution of 5 minutes. For all the 'future' scenarios, we used the same 19 bioclimatic variables as for the 'current' scenario, and these were extracted for each projection, i.e. HadGEM2-AO, rcp26 (HD-26); HadGEM2-AO, rcp85 (HD-85); IPSL-CM5A-LR, rcp26 (IP-26); IPSL-CM5A-LR, rcp85 (IP-85) (Appendix 1).

\section{Species distribution modelling}

Based on worldwide occurrences and important bioclimatic variables, we modelled the current and future (according to the four climate change scenarios) potential habitats in the introduced East Asian range for each species, using the Biomod 2 framework (Thuiller et al, 2013). A combination of different modelling techniques to adjust for the inherent uncertainty of these models was suggested to find the optimal solution from an ensemble of predictions (Araújo \& New, 2007). For each species, therefore, generalized 
linear models (GLM), generalized boosting models (GBM), random forest (RF) and maximum entropy (MaxEnt) were calibrated on a random sample of the initial data $(80 \%)$ and tested on the remaining data sets with both the receiver-operating characteristic (ROC) curve and the true kill statistic (TSS) (Pearce $\&$ Ferrier, 2000). More details on the modeling approach are given in Sun et al (2017). For the predictions under future bioclimatic conditions, we produced maps with mean values and standard deviations from four scenarios of each species. The overlap maps of the six insect species on A. artemisiifolia were then produced based on their current binary maps and the mean binary maps of the four future climate scenarios.

\section{Bioclimatic niche analyses}

Niche overlap between A. artemisiifolia in the native North American (NA) and the invaded East Asian (EA) range was estimated using ordination techniques in the ecospat package in $\mathrm{R}$ (Broennimann et al, 2014). Niches were quantified along the two first axes of a PCA-env based on a correlation matrix of the same nine bioclimatic variables selected for the SDMs of $A$. artemisiifolia. We then used PCA-env in Ecospat to run niche equivalency and similarity tests, which were shown to consistently out-perform other ordination metrics of niche overlap variables (Broennimann et al, 2012; Cola et al, 2016). The niche equivalency examines whether the niche overlap is constant when randomly reallocating the occurrences of both entities among the two ranges, which is repeated 100 times. The niche similarity tests address whether the overlap between observed niches in the two ranges is higher than the overlap between the observed niche in one range and a niche selected at random from the other range. The test was done in both directions (NA $\leftrightarrow$ EA) using 100 repetitions (Broennimann et al, 2012).

All analyses were performed using R statistical software, version 3.3.2 (R Development Core Team 2016).

\section{Results}

\section{Model performance}

Area under the curve (AUC) evaluates the discriminatory power of model predictions that ranged from 0.70 to 0.99 across the three species and four model types in our models. More than $95 \%$ of AUC values were larger than 0.8 (AUC of 0.8 means that in places where a species is present in $80 \%$ of cases the predicted values will be higher than where the species has not been recorded; Wisz et al, 2008; Table 1). Specifically, GBM and RF were generally equally predictive and both tended to be more predictive than GLM and MaxEnt; A. artemisiifolia and $O$. communa had a higher AUC than E. strenuana (Appendix 2). In general, given the high AUC values achieved in all analyses, our models thus yielded acceptable AUC values and provided useful information for an analysis of climate suitability of the studied target invasive plant species $A$. artemisiifolia and the two biological control agents through modelling of the species distributions. Those highly accurate predictions exhibit potential distributions very close to the observed ones. The high AUC values also suggest that it is possible to obtain reasonable distribution predictions in a specifically introduced area using the data worldwide, i.e. from both native range and other introduced ranges.

Table 1 AUC power of all species using four models under current and future climate scenarios showing acceptable AUC scores

\begin{tabular}{lccc}
\hline & $\begin{array}{c}\text { Ambrosia ar } \\
\text { temisiifolia }\end{array}$ & $\begin{array}{c}\text { Ophraella } \\
\text { communa }\end{array}$ & $\begin{array}{c}\text { Epiblema } \\
\text { strenuana }\end{array}$ \\
\hline \multicolumn{2}{c}{ Current climate scenario } & & \\
GLM & $0.88 \pm 0.002$ & $0.88 \pm 0.004$ & $0.84 \pm 0.01$ \\
GBM & $0.89 \pm 0.002$ & $0.90 \pm 0.003$ & $0.89 \pm 0.006$ \\
RF & $0.89 \pm 0.003$ & $0.91 \pm 0.003$ & $0.89 \pm 0.006$ \\
MaxEnt & $0.87 \pm 0.003$ & $0.83 \pm 0.004$ & $0.83 \pm 0.009$
\end{tabular}

HD-26 Future climate scenario: HD-26

$\begin{array}{llll}\text { GLM } & 0.87 \pm 0.003 & 0.87 \pm 0.002 & 0.83 \pm 0.01 \\ \text { GBM } & 0.89 \pm 0.002 & 0.90 \pm 0.002 & 0.90 \pm 0.006 \\ \text { RF } & 0.90 \pm 0.002 & 0.91 \pm 0.002 & 0.91 \pm 0.006 \\ \text { MaxEnt } & 0.86 \pm 0.003 & 0.83 \pm 0.003 & 0.80 \pm 0.01\end{array}$

HD-85 Future climate scenario: HD-85

$\begin{array}{llll}\text { GLM } & 0.88 \pm 0.003 & 0.88 \pm 0.002 & 0.84 \pm 0.008 \\ \text { GBM } & 0.90 \pm 0.003 & 0.92 \pm 0.001 & 0.86 \pm 0.008 \\ \text { RF } & 0.89 \pm 0.003 & 0.92 \pm 0.001 & 0.86 \pm 0.009 \\ \text { MaxEnt } & 0.88 \pm 0.003 & 0.84 \pm 0.003 & 0.78 \pm 0.01\end{array}$

IP-26 Future climate scenario: IP-26

$\begin{array}{llll}\text { GLM } & 0.89 \pm 0.003 & 0.87 \pm 0.002 & 0.87 \pm 0.01 \\ \text { GBM } & 0.90 \pm 0.002 & 0.90 \pm 0.002 & 0.91 \pm 0.008 \\ \text { RF } & 0.91 \pm 0.002 & 0.91 \pm 0.001 & 0.91 \pm 0.008 \\ \text { MaxEnt } & 0.89 \pm 0.003 & 0.85 \pm 0.002 & 0.82 \pm 0.009\end{array}$

IP-85 Future climate scenario: IP-85

\begin{tabular}{llll} 
GLM & $0.87 \pm 0.003$ & $0.87 \pm 0.002$ & $0.88 \pm 0.008$ \\
GBM & $0.89 \pm 0.003$ & $0.90 \pm 0.002$ & $0.91 \pm 0.006$ \\
RF & $0.91 \pm 0.003$ & $0.91 \pm 0.002$ & $0.91 \pm 0.006$ \\
MaxEnt & $0.87 \pm 0.003$ & $0.84 \pm 0.003$ & $0.88 \pm 0.008$ \\
\hline
\end{tabular}

GLM, Generalized linear model; GBM, Generalized boosting model; R, Random forest moldel; MaxEnt, Maximum entropy. 
Geographical overlap between suitable areas for A. artemisiifolia and those for the two insect species

Within 100 years after the introduction of A. artemisiifolia into EA, its range now extends from north-east to south-east of China, Korea and most islands of Japan (Appendix 3), which well corresponds to the latitudinal limits of the distribution in North America (Sun et al, 2017). Under climate change, A. artemisiifolia is predicted to expand its range in China towards south-west and further north-east, while only very little in Korea and Japan, in total by only 2\% (Fig. 1).

Model predictions based on current and four future climate scenarios indicate a larger overlap of $O$. communa than that of $E$. strenuana with the suitable area for A. artemisiifolia in EA, with $O$ communa being more widely distributed in the South of China and in Japan (Fig. 1). However, both O. communa (from $40.3 \%$ to $21.6 \%$ ) and E. strenuana (from $29.8 \%$ to $20.3 \%$ ) show a reduced overlap under future as compared to their current climatic scenarios, and this is especially pronounced for $O$. communa. Under climate change, O. communa is predicted to be less suitable in southern and western China, especially in the provinces of Chongqing, Guizhou, Guangxi, Guangdong and Fujian, while E. strenuana is predicted to be less suitable in the Chinese provinces of Sichuan, Henan, Anhui and Jiangsu, as well as in Japan (Fig. 1). Hence, under current climatic scenarios, a total of $42.9 \%$ of the area suitable for A. artemisiifolia is predicted to be also climatically suitable for at least one of the two biological control agents, but only $29.8 \%$ overlap is predicted under future climatic scenarios (Appendix 4). The predictions of the suitable area of each of three species under current and future climate scenarios are presented in Appendix 3 and 5.

\section{Bioclimatic niche analysis}

For niche detection, we analyzed A. artemisiifolia occurrences in North America and East Asia using PCA-env. The first two PCs explained $86.9 \%$ of the variation in the data $(\mathrm{PC} 1=74.28 \%, \mathrm{PC} 2=12.62 \%$; Fig. 2). The introduced EA niche exhibits a large niche
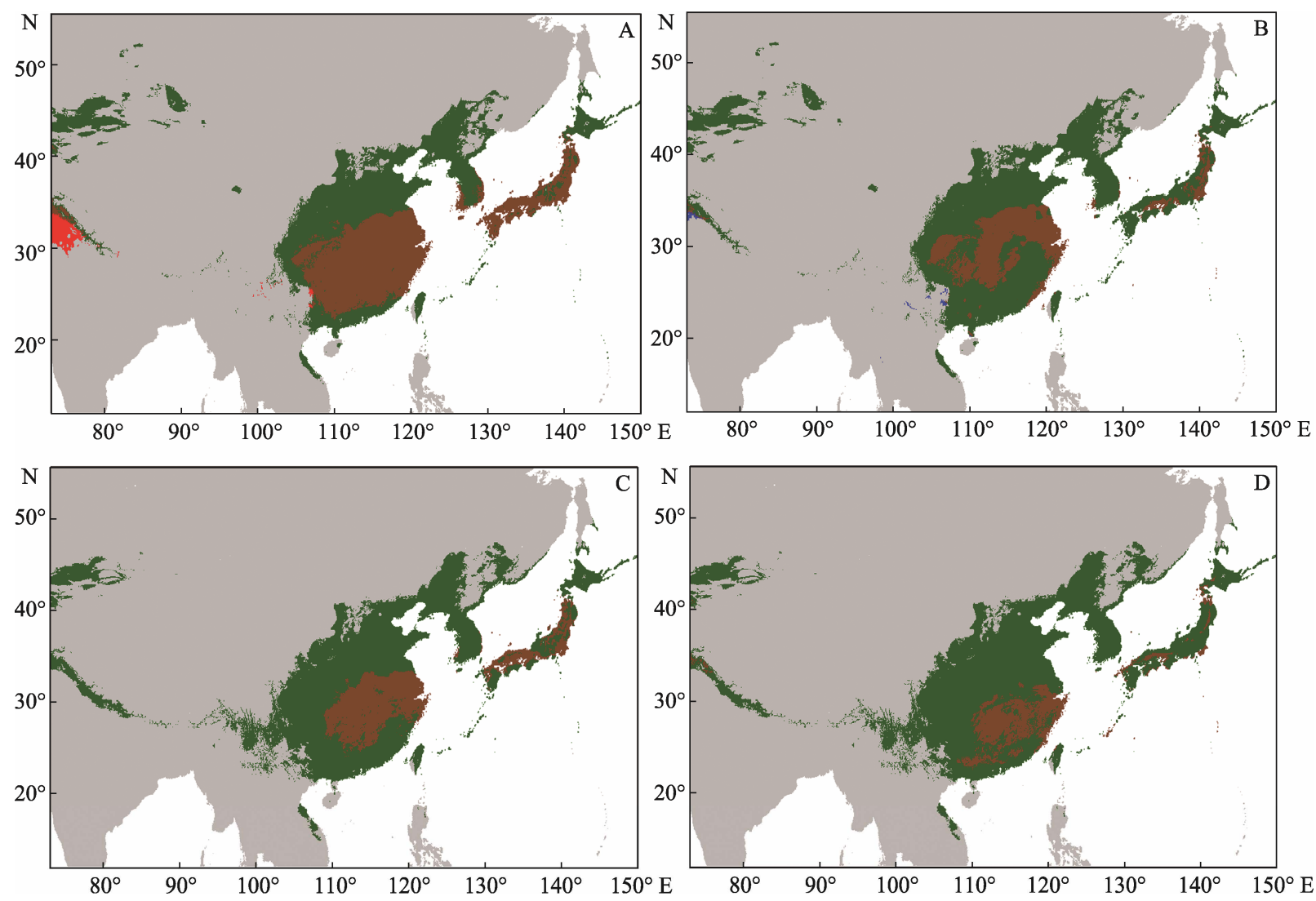

Fig. 1 Geographical predictions of Ambrosia artemisiifolia and two biological control insects for East Asia, under present and future climatic scenarios. The climatic suitability indicates the optimal threshold of the percentage of models predicting each species. Dark green in all figures, A. artemisiifolia, under current climatic conditions: (A) Red, Ophraella communa; sienna, overlap 40.3\%; (B) Blue, Epiblema strenuana; sienna, overlap 21.6\%. Under future climatic scenarios: (C) Red, Ophraella communa; sienna, overlap 29.8\%; (D) Blue, Epiblema strenuana; sienna, overlap 20.3\%. Models calibrated in East Asia only. 

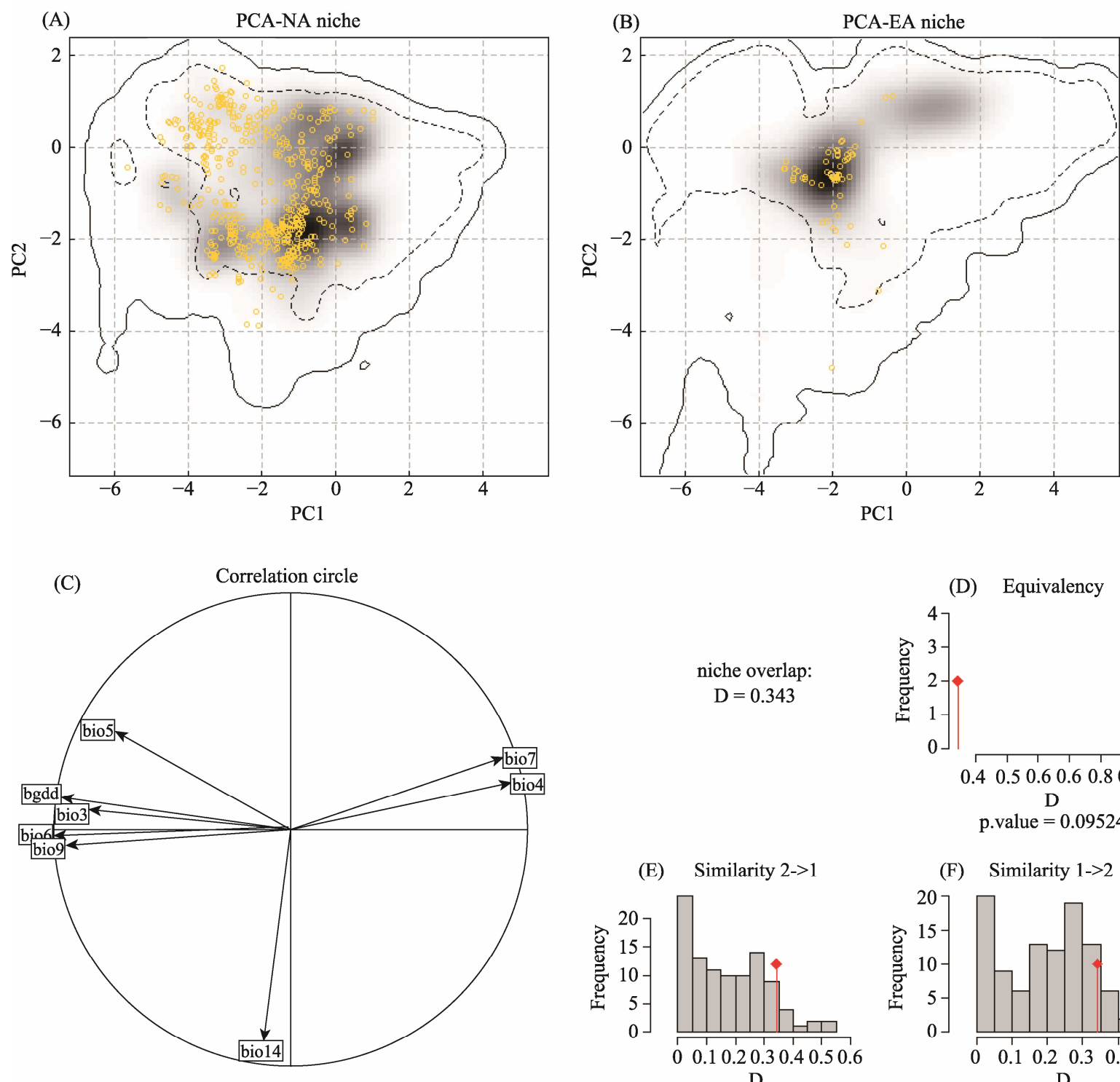

axis $1=74.28 \%$ axis $2=12.62 \%$

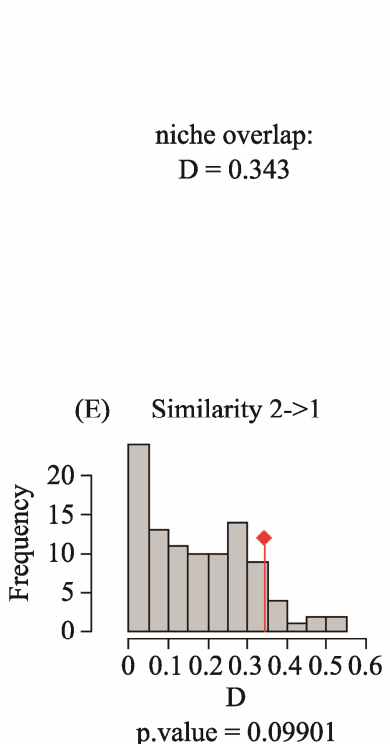

(D) Equivalency

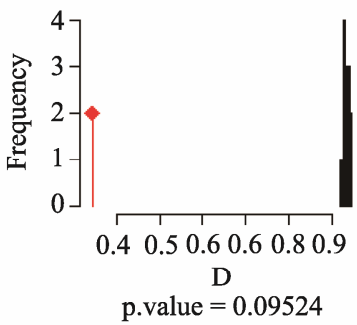

(E) Similarity 2->1

(F) Similarity 1->2

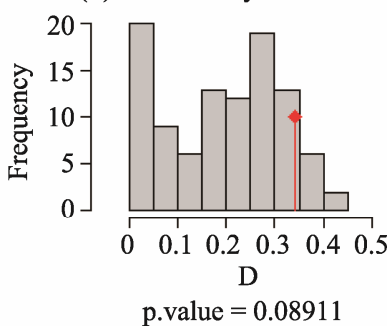

Fig. 2 Niche of Ambrosia artemisiifolia in climatic space using principal component analysis (PCA-env). Panels (A) and (B) represent the niche of the species along the two first axes of the PCA for the native North American (NA) and introduced East Asian (EA) range, respectively. Gray shading shows the density of the occurrences of the species by the cell. The solid contour lines illustrate 100 percent of the available environment, and dashed lines indicate the 50 percent of the most common background environment. Yellow circles in (A) and (B) give the occurrences of two insect species in NA and in EA. The contribution of the climatic variables of the two axes of the PCA and the percentage of inertia explained by the two axes is given in (C). Histograms (D-F) show the observed niche overlap D between the two ranges (bars and a diamond) and simulated niche overlaps (gray bars) on which tests of niche equivalency (D), niche similarity of EA and NA (E), and niche similarity of NA to EA (F) are calculated from 100 iterations, with the significance level of the tests.

unfilling compared to the native NA niche along the $\mathrm{x}$-axis towards cooler summers and higher temperature seasonality (Fig. 2A-C). In addition, Fig. 2B also shows a small niche shift towards decreased precipitation of the driest month in EA. Niche equivalency and both way niche similarity are rejected between the NA and EA niche $(P>0.09)$, indicating that $A$. artemisiifolia has undergone a significant alteration of its enviro- nmental niche during the invasion process (Fig. 2 D-F). Occurrences of the two agents very well cover the niche of A. artemisiifolia in NA, but this is not yet the case for the cooler and dryer niche in EA (Fig. 2A, B).

\section{Discussion}

In view of predicting the effect of global climate 
change on the biological control program of A. artemisiifolia in East Asia, we modelled simultaneously the distributions of the plant invader and two of its biological control agents both under current and future climatic conditions.

\section{Predicted species distributions}

The niche unfilling by A. artemisiifolia in EA was towards cooler and increased temperature seasonality areas, confirming earlier finding by Petitpierre et al (2012) and Sun et al (2017) for the introduced range of A. artemisiifolia in Europe. The predicted distribution maps further suggest more than half of the suitable area of A. artemisiifolia in EA to be presently unsuitable for the two biological control agents, which is considerably smaller compared to the situation in NA, where the suitable range of the two insect species was found to cover ca. $70 \%$ of the suitable A. artemisiifolia habitats (Sun et al, 2017). These unsuitable areas in EA are located in Northern and Central China, most of Korea and Northern Japan (Fig. 1). The low suitability prediction in South Korea may be due to the lack of occurrences in our models. The realized niche in EA shows that the niche uncovered by the two agents is mainly in the cooler and drier areas with increased temperature seasonality, which is in line with our geographic predictions.

Using the mean of the four future bioclimatic scenarios well represents the predicted future overlap between the plant and the insects in EA, although there is some species-specific variation. The spatial overlap of the suitable area for A. artemisiifolia and its two agents is further reduced by climate change ( $42.9 \%$ vs. $29.8 \%$, for current and future climate, respectively). Especially the cover of $O$. communa on the suitable area of A. artemisiifolia drops from $40.3 \%$ to $29.8 \%$, which however is in line with the prediction for Europe (Sun et al, 2017). A possible explanation for this reduced biological control opportunity in EA under climate change is that future warmer summers, later autumn frosts and increased temperature seasonality will allow north- and west-ward spread of $A$. artemisiifolia, but not of the two insect species, as the invasive plant species and its biological control agents do not necessarily react in a similar manner to climate change (Schweiger et al, 2008; Barriopedro et al, 2011; Björkman \& Niemelä, 2015).

\section{Management implications}

We found that a large part of the geographic range of A. artemisiifolia in western and northern China, Korea and northern Japan will not be suitable for the two biological control agents. Our analysis also indicates the $O$. communa is not suitable for Korea, and $E$. strenuana is not suitable for most areas in Japan and Korea. Besides the possibility to explore on introducing additional biological control agents to cover these gaps (cf. Gerber et al, 2013), specific strains of the two study species could be selected for to cover the present and future A. artemisiifolia range in EA presently unsuitable for these insects. For this, our niche analysis clearly indicates the abiotic conditions to select for in order to develop adapted strains for these areas, which would include selecting for lower summer temperatures and increased temperature seasonality. For this, genetic variation in relevant performance traits will be crucial, but, so far, measures of genetic variation in functional traits have rarely been studied in biological control agents (Roderick et al, 2012). Previous research with $O$. communa reported genetic variation in relevant performance traits, such as for flight activity (Tanaka, 2009) and photoperiod response to environmental conditions (Tanaka et al, 2015). Similarly, Zhou et al (2013) selected strains of $O$. communa adapted to cold temperatures by cold acclimation in the previous generation to facilitate their range expansion towards northern China and thus to track their host-plants into colder climate and to build-up higher densities through an increased number of generations in these areas. Specific selection regimes during commercial mass productions could thus greatly speed up the development of strains adapted to the yet uncovered A. artemisiifolia area in EA.

We acknowledge that studies on the demographic interactions between the invasive alien plant and its biological control agents are important to further improve the accuracy of predictions of the distribution dynamics and thus the management success of this prominent plant invader.

\section{Acknowledgement}

We acknowledge financial support from the Advance Postdoc. Mobility fellowship from the Swiss National Science Foundation (SNSF; project no. P300PA-161014 to YS), the Swiss State Secretariat for Education, Research, and Innovation (SERI, grant number-13.0146 to HMS), the Swiss National Science Foundation (SNSF grant no. 31003A_166448/1 to HMS) and the EU COST Action FA1203 'Sustainable management of Ambrosia artemisiifolia in Europe (SMARTER to HMS)'.

\section{References}

Araújo MB, New M (2007) Ensemble forecasting of species distributions. Trends in Ecology \& Evolution, 22, 42-47.

Barriopedro D, Fischer EM, Luterbacher J, Trigo RM, García-Herrera R (2011) The hot summer of 2010: redrawing 
the temperature record map of Europe. Science, 332, 220-224.

Björkman C, Niemelä P (2015) Climate Change and Insect Pests. CABI, Oxfordshire, UK.

Broennimann O, Fitzpatrick MC, Pearman PB, Petitpierre B, Pellissier L, Yoccoz NG, Thuiller W, Fortin MJ, Randin C, Zimmermann NE (2012) Measuring ecological niche overlap from occurrence and spatial environmental data. Global Ecology and Biogeography, 21, 481-497.

Broennimann O, Petitpierre B, Randin C, Engler R, Breiner F, Manuela D, Pellissier L, Pottier J, Pio D, Mateo RG (2014) Package 'ecospat'. https://cran.r-project.org/web/ packages/ecospat/index.html.

Cola VD, Broennimann O, Petitpierre B, Breiner FT, D'Amen M, Randin C, Engler R, Pottier J, Pio D, Dubuis A (2016) ecospat: an $\mathrm{R}$ package to support spatial analyses and modeling of species niches and distributions. Ecography, 40, 774-787.

Essl F, Biró K, Brandes D, Broennimann O, Bullock JM, Chapman DS, Chauvel B, Dullinger S, Fumanal B, Guisan A (2015) Biological flora of the British Isles: Ambrosia artemisiifolia. Journal of Ecology, 103, 1069-1098.

Fukano Y, Doi H (2013) Population abundance and host use pattern of Ophraella communa (Coleoptera: Chrysomeli dae) in its native and introduced range. Biocontrol Science and Technology, 23, 595-601.

Fukano Y, Yahara T (2012) Changes in defense of an alien plant Ambrosia artemisiifolia before and after the invasion of a native specialist enemy Ophraella communa. PLoS ONE, 7, e49114.

Futuyma DJ, McCafferty SS (1990) Phylogeny and the evolution of host plant associations in the leaf beetle genus Ophraella (Coleoptera, Chrysomelidae). Evolution, 44, 1885-1913.

Gerber E, Schaffner U, Gassmann A, Hinz H, Seier M, Müller-Schärer H (2011) Prospects for biological control of Ambrosia artemisiifolia in Europe: learning from the past. Weed Research, 51, 559-573.

Gillson L, Dawson TP, Jack S, McGeoch MA (2013) Accommodating climate change contingencies in conservation strategy. Trends in Ecology \& Evolution, 28, 135-142.

Giorgetta MA, Jungclaus J, Reick CH, Legutke S, Bader J, Böttinger M, Brovkin V, Crueger T, Esch M, Fieg K (2013) Climate and carbon cycle changes from 1850 to 2100 in MPI-ESM simulations for the Coupled Model Intercomparison Project phase 5. Journal of Advances in Modeling Earth Systems, 5, 572-597.

Goolsby JA, De Barro PJ, Kirk AA, Sutherst RW, Canas L, Ciomperlik MA, Ellsworth PC, Gould JR, Hartley DM, Hoelmer KA (2005) Post-release evaluation of biological control of Bemisia tabaci biotype "B" in the USA and the development of predictive tools to guide introductions for other countries. Biological Control, 32, 70-77.

Guisan A, Zimmermann NE (2000) Predictive habitat distribution models in ecology. Ecological Modelling, 135, $147-186$.
Hannah L, Midgley GF, Millar D (2002) Climate change-integrated conservation strategies. Global Ecology and Biogeography, 11, 485-495.

Hijmans RJ, Cameron SE, Parra JL, Jones PG, Jarvis A (2005) Very high resolution interpolated climate surfaces for global land areas. International Journal of Climatology, 25, 1965-1978.

Hisauchi K (1950) Naturalized Plants. Kagakutosyo syuppan, Tokyo.

Hoelmer K, Kirk A (2005) Selecting arthropod biological control agents against arthropod pests: Can the science be improved to decrease the risk of releasing ineffective agents? Biological Control, 34, 255-264.

IPCC (2013) Climate Change 2013: The Physical Science Basis. http://www.climatechange2013.org/

Kettenring KM, Adams CR (2011) Lessons learned from invasive plant control experiments: a systematic review and meta-analysis. Journal of Applied Ecology, 48, 970-979.

LeSage L (1986) A taxonomic monograph of the Nearctic galerucine genus Ophraella Wilcox (Coleoptera: Chrysomelidae). Memoirs of the Entomological Society of Canada, 118, 3-75.

Li HK, Li M, Li D (1999) Ambrosia artemisiifolia and its biological control. World Agriculture, (8), 40-41. (in Chinese)

Ma J, Guo JY, Wan FH, Hu X, Wan FH, Li B, Guo J (2008) Biological control of Ambrosia artemisiifolia and A. trifida. In: Biological Invasions: Biological Control Theory and Practice, pp. 157-185. Science Press, Beijing. (in Chinese with English abstract)

McFadyen RC (1992) Biological control against Parthenium weed in Australia. Crop Protection, 11, 400-407.

Messenger P, van den Bosch R (1971) The adaptability of introduced biological control agents. In: Biological Control (ed. Huffaker CB), pp. 68-92. Springer, Boston.

Moriya S, Shiyake S (2001) Spreading the distribution of an exotic ragweed beetle, Ophraella communa LeSage (Coleoptera: Chrysomelidae), in Japan. Japanese Journal of Entomology (New Series), 4, 99-102.

Mukherjee A, Christman MC, Overholt WA, Cuda JP (2011) Prioritizing areas in the native range of hygrophila for surveys to collect biological control agents. Biological Control, 56, 254-262.

Müller-Schärer H, Schaffner U (2008) Classical biological control: exploiting enemy escape to manage plant invasions. Biological Invasions, 10, 859-874.

Palmer W, Goeden R (1991) The host range of Ophraella communa LeSage (Coleoptera: Chrysomelidae). The Coleopterists' Bulletin, 45, 115-120.

Pearce J, Ferrier S (2000) Evaluating the predictive performance of habitat models developed using logistic regression. Ecological Modelling, 133, 225-245.

Peterson AT (2003) Predicting the geography of species' invasions via ecological niche modeling. The Quarterly Review of Biology, 78, 419-433.

Peterson AT (2011) Ecological niches and geographic distribu- 
tions (MPB-49). Princeton University Press, New Jersey.

Petitpierre B, Kueffer C, Broennimann O, Randin C, Daehler C, Guisan A (2012) Climatic niche shifts are rare among terrestrial plant invaders. Science, 335, 1344-1348.

R Core Team (2016) R: A language and environment for statistical computing. R Foundation for Statistical Computing, Vienna, Austria. http://www.R-project.org/.

Roderick GK, Hufbauer R, Navajas M (2012) Evolution and biological control. Evolutionary Applications, 5, 419-423.

Schweiger O, Settele J, Kudrna O, Klotz S, Kühn I (2008) Climate change can cause spatial mismatch of trophically interacting species. Ecology, 89, 3472-3479.

Seastedt TR (2015) Biological control of invasive plant species: a reassessment for the Anthropocene. New Phytologist, 205, 490-502.

Sun Y, Brönnimann O, Roderick GK, Poltavsky A, Lommen STE, Müller-Schärer H (2017) Climatic suitability ranking of candidate biological control agents for weeds: a biogeographic approach for ragweed management in Europe under present and future climatic conditions. Ecosphere, 8, e01731.

Tanaka K (2009) Genetic variation in flight activity of Ophraella communa (Coleoptera: Chrysomelidae): heritability estimated by artificial selection. Environmental Entomology, 38, 266-273.

Tanaka K, Murata K, Matsuura A (2015) Rapid evolution of an introduced insect Ophraella communa LeSage in new environments: temporal changes and geographical differences in photoperiodic response. Entomological Science, 18, 104-112.

Theoharides KA, Dukes JS (2007) Plant invasion across space and time: factors affecting nonindigenous species success during four stages of invasion. New Phytologist, 176, 256-273.

Thuiller W, Georges D, Engler R (2013) Biomod2: ensemble platform for species distribution modeling. $\mathrm{R}$ package. http://CRAN. R-project. org/package= biomod2.

Vilà M, Espinar JL, Hejda M, Hulme PE, Jarošík V, Maron JL, Pergl J, Schaffner U, Sun Y, Pyšek P (2011) Ecological impacts of invasive alien plants: a meta-analysis of their effects on species, communities and ecosystems. Ecology Letters, 14, 702-708.

Walker B, Steffen W (1997) An overview of the implications of global change for natural and managed terrestrial ecosystems. Conservation Ecology, 1, 2.

Walther G-R, Roques A, Hulme PE, Sykes MT, Pyšek P, Kühn I, Zobel M, Bacher S, Botta-Dukát Z, Bugmann H (2009) Alien species in a warmer world: risks and opportunities. Trends in Ecology \& Evolution, 24, 686-693.

Wan FH, Liu WX, Ma J, Guo J (2005) Ambrosia artemisiifolia and A. trifida. In: Biology and Management of Invasive Alien Species in Agriculture and Forestry (eds Wan FH, Zheng XB, Guo JY), pp. 662-688. Science Press, Beijing. (in Chinese)

Wan FH, Guan GQ, Wang R (1993) Ambrosia and Its Comprehensive Administration. Chinese Science and Technology Press, Beijing. (in Chinese)

Winston RL, Schwarzländer M, Hinz HL, Day MD, Cock MJW, Julien MH (2014) Biological Control of Weeds: A World Catalogue of Agents and Their Target Weeds, 5th edn. USDA Forest Service, Forest Health Technology Enterprise Team, Virginia.

Wisz MS, Hijmans R, Li J, Peterson AT, Graham C, Guisan A (2008) Effects of sample size on the performance of species distribution models. Diversity and Distributions, 14, 763-773.

Yamazaki K, Imai C, Natuhara Y (2000) Rapid population growth and food-plant exploitation pattern in an exotic leaf beetle, Ophraella communa LeSage (Coleoptera: Chrysomelidae), in western Japan. Applied Entomology and Zoology, 35, 215-223.

Zhou ZS, Chen HS, Zheng XW, Guo JY, Guo W, Li M, Luo M, Wan FH (2014) Control of the invasive weed Ambrosia artemisiifolia with Ophraella communa and Epiblema strenuana. Biocontrol Science and Technology, 24, 950-964.

Zhou ZS, Guo JY, Chen HS, Wan FH (2010) Effects of temperature on survival, development, longevity, and fecundity of Ophraella communa (Coleoptera: Chrysomelidae), a potential biological control agent against Ambrosia artemisiifolia (Asterales: Asteraceae). Environmental Entomology, 39, 1021-1027.

Zhou ZS, Guo JY, Michaud JP, Li M, Wan FH (2011a) Variation in cold hardiness among geographic populations of the ragweed beetle, Ophraella communa LeSage (Coleoptera: Chrysomelidae), a biological control agent of Ambrosia artemisiifolia L. (Asterales: Asteraceae), in China. Biological Invasions, 13, 659-667.

Zhou ZS, Guo JY, Wan FH (2015) Review on management of Ambrosia artemisiifolia using natural enemy insects. Chinese Journal of Biological Control, 31, 657-665.

Zhou ZS, Guo JY, Zheng XW, Luo M, Chen HS, Wan FH (2011b) Reevaluation of biosecurity of Ophraella communa against sunflower (Helianthus annuus). Biocontrol Science and Technology, 21, 1147-1160.

Zhou ZS, Rasmann S, Li M, Guo JY, Chen HS, Wan FH (2013) Cold temperatures increase cold hardiness in the next generation Ophraella communa beetles. PLoS ONE, 8, e74760.

(Handling editor: Yizhuan Shi)

\section{Supplementary Material}

Appendix 1 List of all 19 predictors available in WORLDCLIM bioclimatic data set and growth degree days (GDD) http://www.biodiversity-science.net/fileup/PDF/2017096-1.pdf 
Appendix 2 Differences in discrimination ability (AUC) across all levels http://www.biodiversity-science.net/fileup/PDF/2017096-2.pdf

Appendix 3 Geographic continence predictions of Ambrosia artemisiifolia and its two biological control agents, Ophraella communa and Epibleama strenuana under present climatic scenarios in East Asia with occurrences presented.

http://www.biodiversity-science.net/fileup/PDF/2017096-3.pdf

Appendix 4 Geographic predictions of overlap of Ambrosia artemisiifolia and its two biological control agents Ophraella communa and Epiblema strenuana under present and future climatic scenarios in East Asia.

http://www.biodiversity-science.net/fileup/PDF/2017096-4.pdf

Appendix 5 Mean and standard deviation of geographic predictions of Ambrosia artemisiifolia and its two biological control agents Ophraella communa and Epiblema strenuana under four future climatic scenarios in East Asia.

http://www.biodiversity-science.net/fileup/PDF/2017096-5.pdf 
孙燕, 周忠实, 王瑞, Heinz Müller-Schärer. 气候变化预计会减少东亚地区豚草的生物防治效果. 生物多样性, 2017, 25(12): 1285-1294. http://www.biodiversity-science.net/CN/10.17520/biods.2017096

附录1 WORLDCLIM的生物气候数据集的19个生物气候因子和生长有效积温

Appendix 1 List of all 19 predictors available in WORLDCLIM bioclimatic data set and growth degree days (GDD)

\begin{tabular}{|c|c|}
\hline WORLDCLIM Variable & Description \\
\hline BIO1 & Annual mean temperature \\
\hline $\mathrm{BIO} 2$ & Mean diurnal range \\
\hline $\mathrm{BIO} 3$ & Isothermality \\
\hline $\mathrm{BIO} 4$ & Temperature seasonality \\
\hline BIO5 & Max temperature of warmest month \\
\hline BIO6 & Min temperature of coldest month \\
\hline $\mathrm{BIO} 7$ & Temperature annual range \\
\hline $\mathrm{BIO} 8$ & Mean temperature of wettest quarter \\
\hline BIO9 & Mean temperature of driest quarter \\
\hline $\mathrm{BIO} 10$ & Mean temperature of warmest quarter \\
\hline BIO11 & Mean temperature of coldest quarter \\
\hline $\mathrm{BIO} 12$ & Annual precipitation \\
\hline $\mathrm{BIO} 13$ & Precipitation of wettest month \\
\hline $\mathrm{BIO} 14$ & Precipitation of driest month \\
\hline $\mathrm{BIO} 15$ & Precipitation seasonality \\
\hline $\mathrm{BIO} 16$ & Precipitation of wettest quarter \\
\hline $\mathrm{BIO} 17$ & Precipitation of driest quarter \\
\hline $\mathrm{BIO} 18$ & Precipitation of warmest quarter \\
\hline BIO19 & Precipitation of coldest quarter \\
\hline GDD & Growing degree days (based on monthly average temperatures using Thom's formula) \\
\hline
\end{tabular}


孙燕, 周忠实, 王瑞, Heinz Müller-Schärer. 气候变化预计会减少东亚地区豚草的生物防治效果. 生物多样性, 2017, 25(12): 1285-1294. http://www.biodiversity-science.net/CN/10.17520/biods.2017096
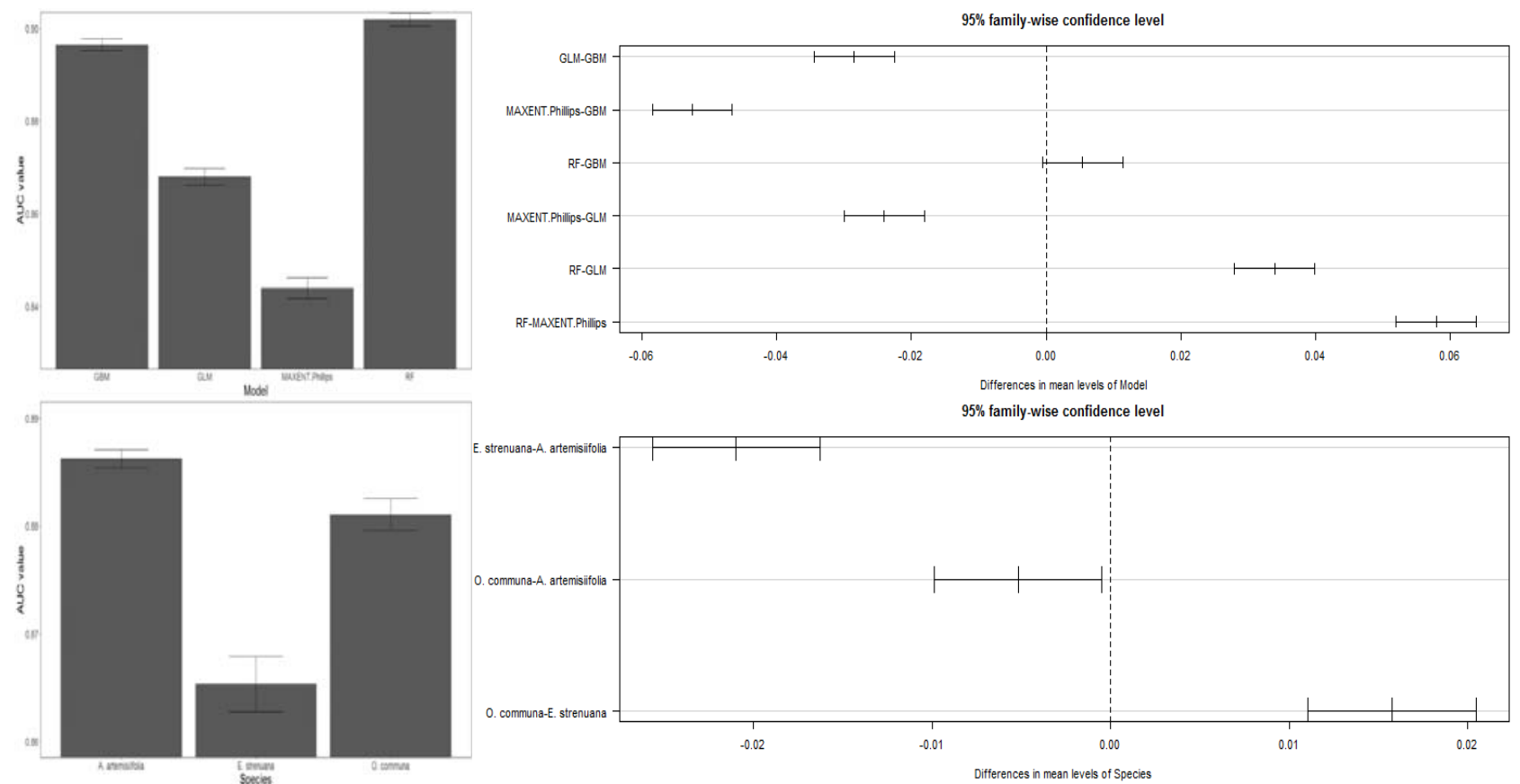

95\% family-wise confidence level
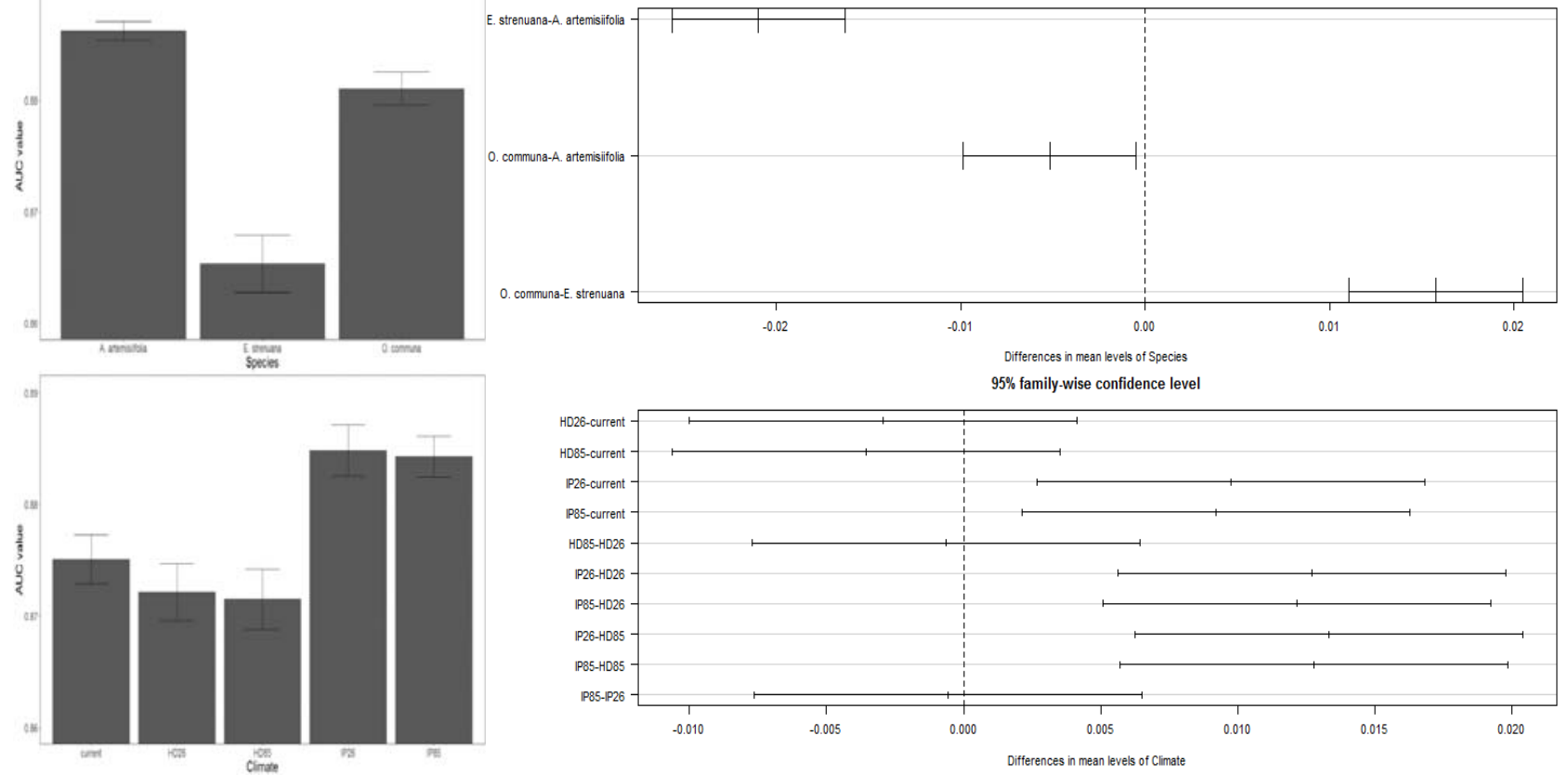

95\% family-wise confidence level

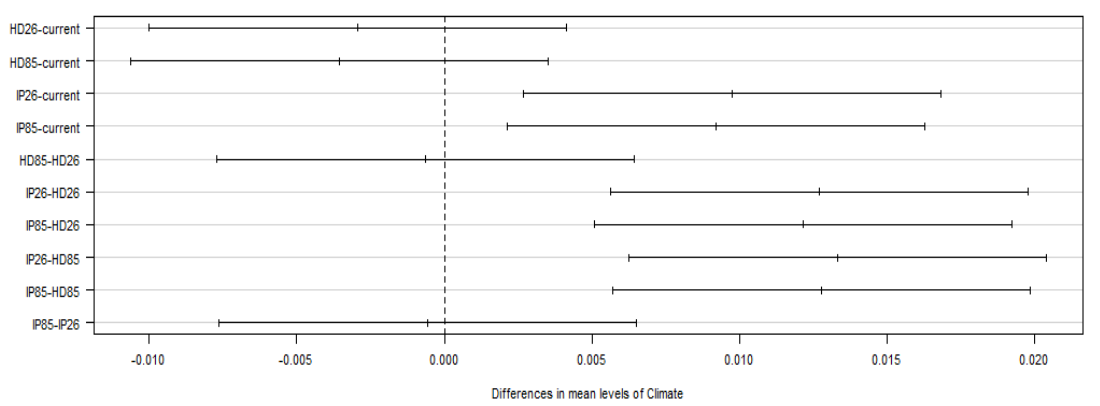

附录2 模型预测能力(AUC)的差异

Appendix 2 Differences in discrimination ability (AUC) across all levels 
孙燕, 周忠实, 王瑞, Heinz Müller-Schärer. 气候变化预计会减少东亚地区豚草的生物防治效果. 生物多样性, 2017, 25(12): 1285-1294. http://www.biodiversity-science.net/CN/10.17520/biods.2017096
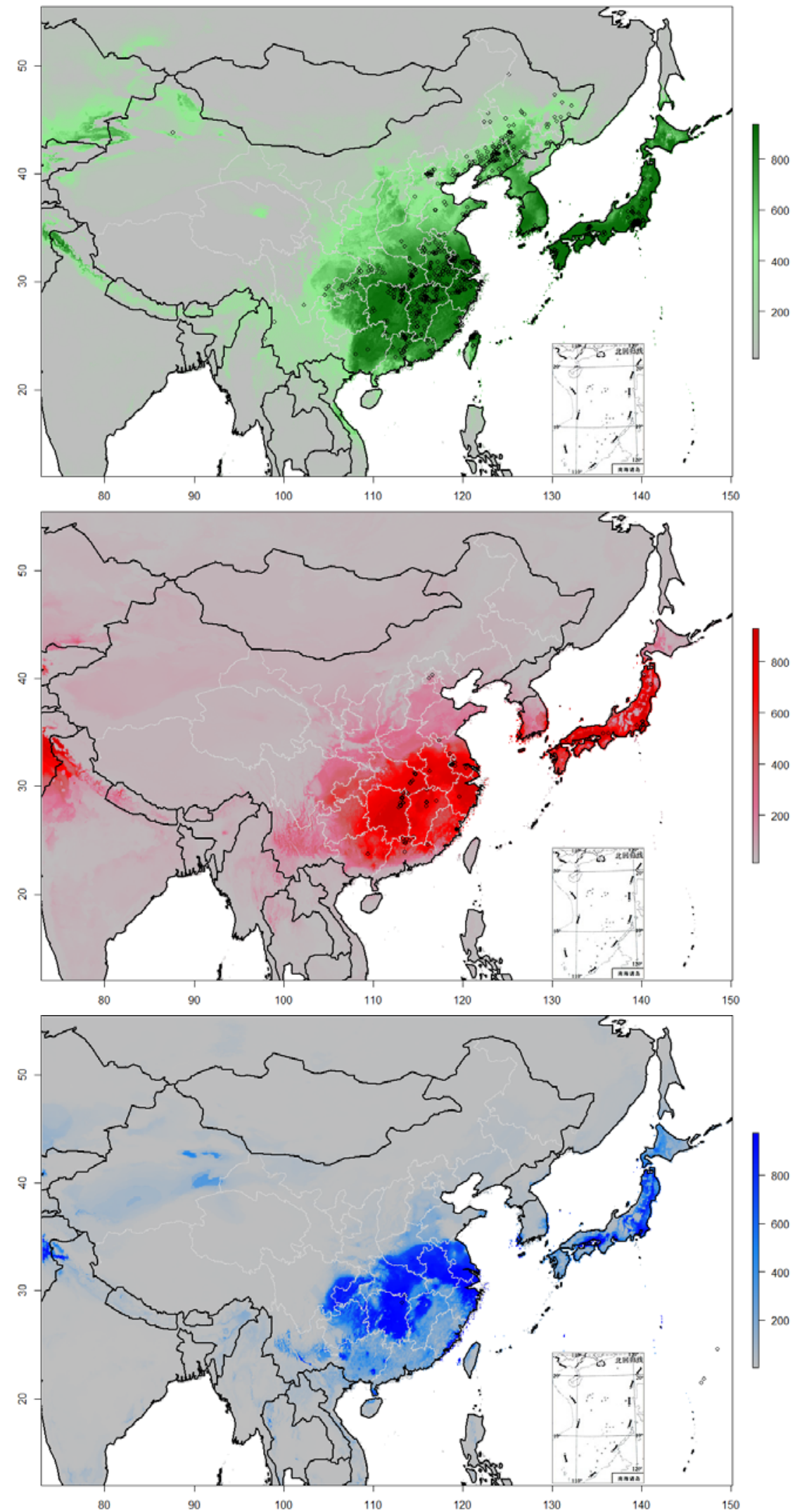

附录3 在当前气候情景下, 利用观察记录预测的东亚地区豚草和它的两种天敌的地理分布

Appendix 3 Geographic continence predictions of Ambrosia artemisiifolia and its two biological control agents, Ophraella communa and Epibleama strenuana under present climatic scenarios in East Asia with occurrences presented. 


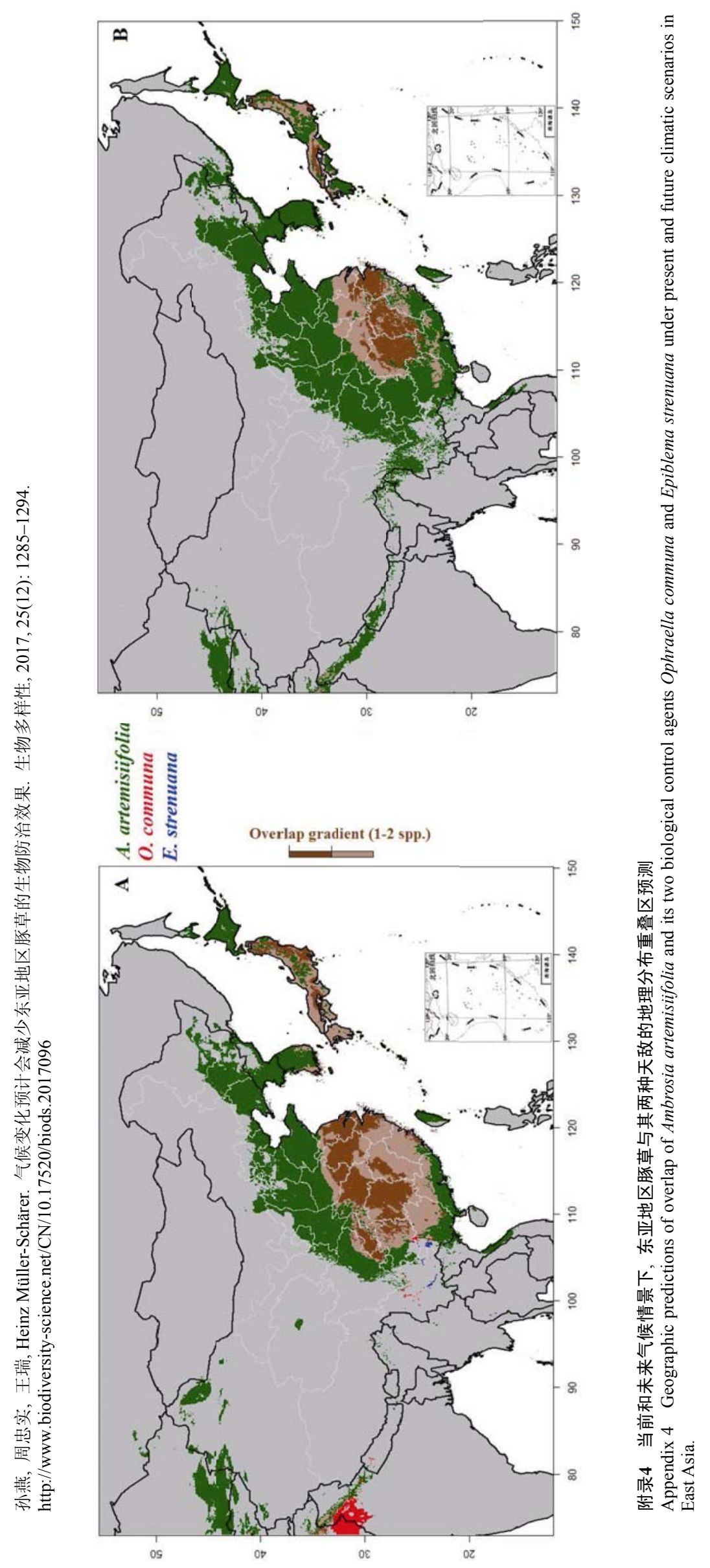


Mean prediction
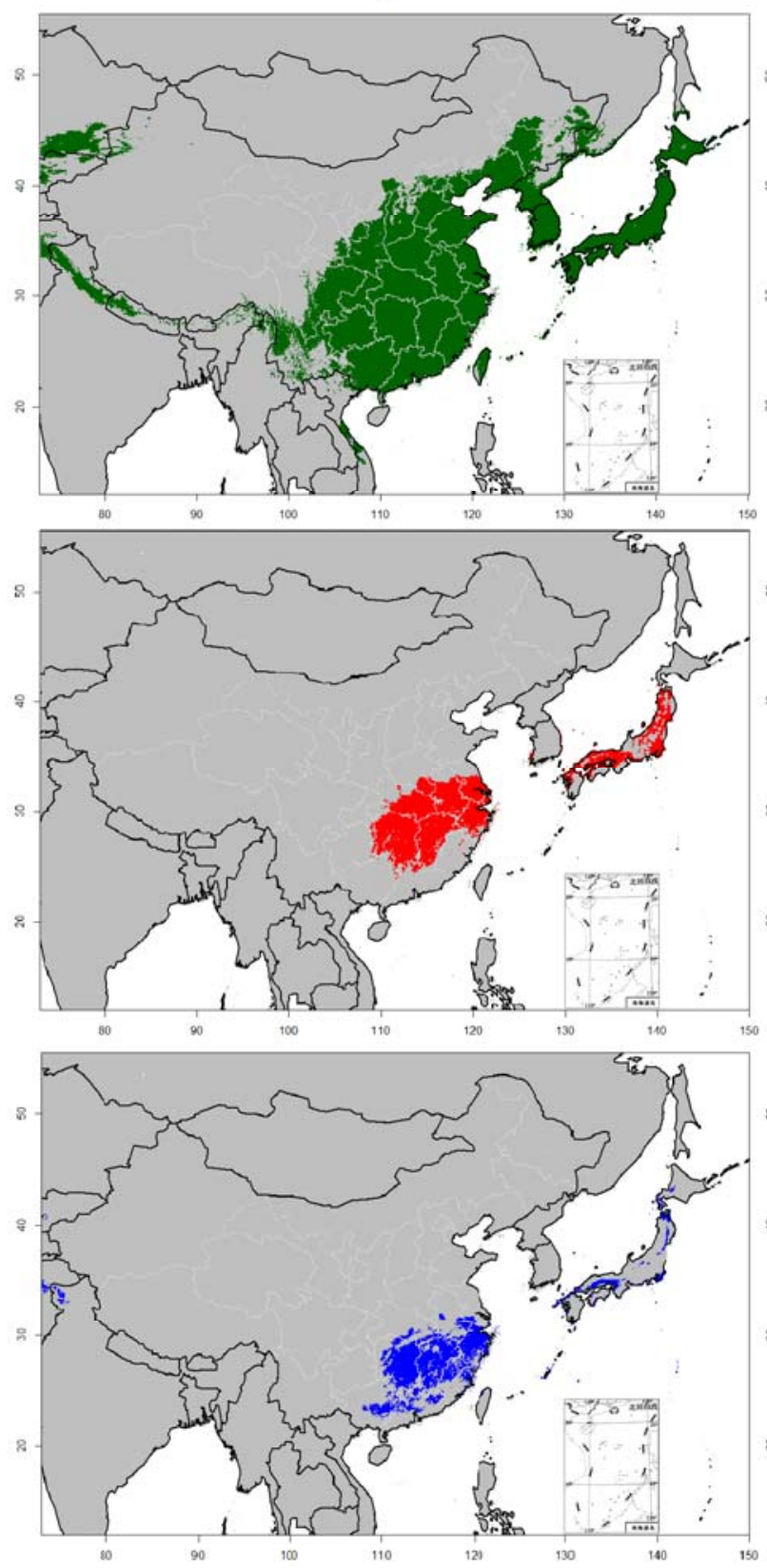

Standard deviation
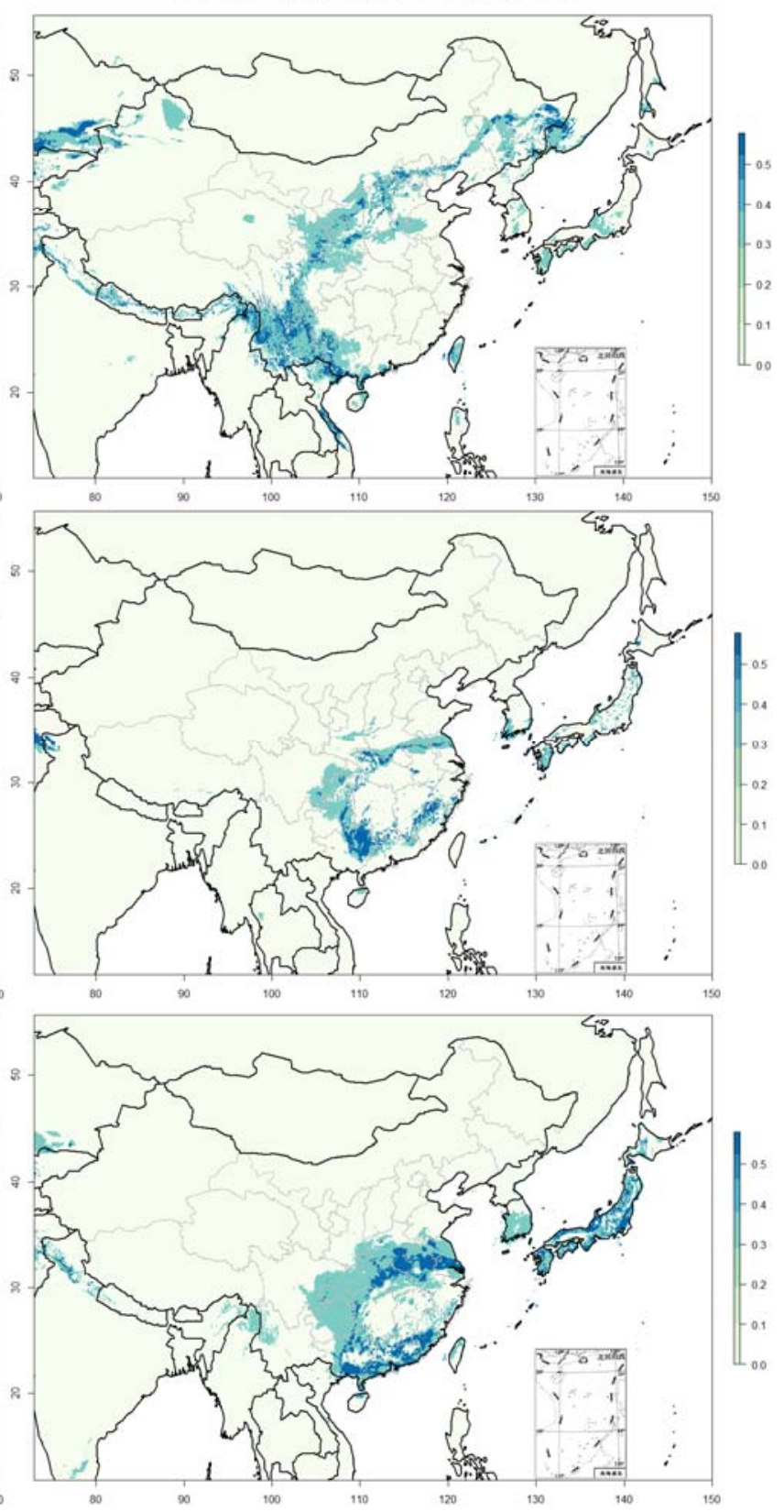

附录5 在未来气候情境下, 东亚地区豚草及两种天敌的地理分布预测的平均值和标准差

Appendix 5 Mean and standard deviation of geographic predictions of Ambrosia artemisiifolia and its two biological control agents Ophraella communa and Epiblema strenuana under four future climatic scenarios in East Asia. 
•生物入侵专题・

\title{
气候变化预计会减少东亚地区豚草的 生物防治效果 ${ }^{* *}$
}

\author{
孙 燕 ${ }^{1^{*}}$ 周忠实 ${ }^{2}$ 王 瑞 ${ }^{2}$ Heinz Müller-Schärer ${ }^{3}$ \\ 1 (Plant Evolutionary Ecology, University of Tübingen, 72076 Tübingen, Germany) \\ 2 (中国农业科学院植物保护研究所, 植物病虫害生物学国家重点实验室, 北京 100193) \\ 3 (Department of Biology/Ecology \& Evolution, University of Fribourg, 1700 Fribourg, Switzerland)
}

\begin{abstract}
摘要: 外来入侵植物对入侵地的生态系统与社会经济可造成严重的威胁。如何控制入侵植物对自然资源的危害, 向人类提出了极大的挑战。利用原产地的专食性天敌来控制入侵植物已被广泛证明是一种经济、可持续的生物防 治手段。在全球气候变暖的背景下, 生物防治研究的关键问题是全面了解物种的潜在分布区和传播范围, 进而优 化入侵植物的生物防治方案。本研究利用生物地理模型, 通过预测两种生物防治昆虫和它们的组合在东亚地区的 适宜分布区，预测豚草(Ambrosia artemisiifolia)的生物防治区域。豚草原产北美，目前已经入侵全球多个国家和地 区。20世纪末, 豚草条纹叶甲 (Ophraella communa) 和豚草卷蛾 (Epiblema strenuana) 作为豚草的生物防治昆虫从原 产地引入到东亚地区。本研究旨在探讨如下问题: (1)在豚草的适宜生长分布区内, 有多少区域也同样适宜其两种 天敌的生存? (2)在目前和未来的气候背景下, 有多少区域适宜豚草生长但是不适宜它的两种天敌生长? (3)在这 些适宜豚草生长却不适宜两种昆虫天敌生长的区域内，需要选择哪些特定的生物型进行投放？为此，我们基于入 侵植物和两种生物防治昆虫的全球分布记录及其分布点的重要生物气候因子, 同时模拟了入侵植物及其两种生物 防治天敌在东亚地区的分布范围。排序技术被用来探索气候因子对每个物种的限制作用，同时也用来检验豚草在 北美和东亚地区的生态位重叠和相似性。结果表明, 在当前和未来的气候背景下, 相较于豚草卷蛾, 豚草条纹叶 甲与豚草的地理分布范围更加吻合 (当前气候: $40.3 \%$ vs. $21.6 \%$, 未来气候: $29.8 \%$ vs. $20.3 \%$ )。气候变化可能会导 致两种生物防治天敌(尤其是豚草条纹叶甲)的地理分布与豚草的地理分布的重叠区域减少 (42.9\% vs. $29.9 \%$ )。本 研究同时提出了温度和降水等气候因子可用于为特殊区域(生物防治天敌未覆盖的豚草分布区)笁选生物防治天敌 的相应株系。
\end{abstract}

关键词: 生物防治; 生物入侵; 豚草卷蛾; 生态位重叠; 豚草条纹叶甲; 物种分布

\section{Biological control opportunities of ragweed are predicted to decrease with climate change in East Asia}

\author{
Yan Sun ${ }^{1 *}$, Zhongshi Zhou ${ }^{2}$, Rui Wang ${ }^{2}$, Heinz Müller-Schärer ${ }^{3}$ \\ 1 Plant Evolutionary Ecology, University of Tübingen, 72076 Tübingen, Germany \\ 2 State Key Laboratory for Biology of Plant Diseases and Insect Pests, Institute of Plant Protection, Chinese Academy of \\ Agricultural Sciences, Beijing 100193, China \\ 3 Department of Biology/ Ecology \& Evolution, University of Fribourg, 1700 Fribourg, Switzerland
}

\begin{abstract}
The control of invasive alien plants (IAP) that jeopardize our ecosystems and economy constitutes a significant challenge for natural resource management. Classical biological control referring to the introduction of specialist antagonists from the native range has proven to be a highly cost-effective management tool against IAP. A critical issue in biological control research is to guide informed decision-making on the

收稿日期: 2017-03-24; 接受日期: 2017-06-10

基金项目: The Advance Postdoc. Mobility fellowship from the Swiss National Science Foundation (SNSF: P300PA-161014 to YS). The Swiss State Secretariat for Education, Research, and Innovation (SERI: 13.0146 to HMS). The Swiss National Science Foundation (SNSF: 31003A 166448/1 to HMS) and the EU COST Action FA1203 'Sustainable management of Ambrosia artemisiifolia in Europe (SMA-RTER to HMS)'

* 通讯作者 Author for correspondence. E-mail: yansun.ecology@gmail.com

**The English version of this paper is available at: http://www.biodiversity-science.net/fileup/PDF/2017096-6.pdf
\end{abstract}


potential spread and distribution and thus impact of biological control candidates, especially under climate change. Here we propose a biogeographic modeling approach to predict the cover of the suitable area of a plant invader in East Asia (EA) by two biological control agents and their combinations. Our study system is Ambrosia artemisiifolia, native to North America and invasive worldwide, and two North American biological control agents, Ophraella communa and Epiblema strenuana that were accidentally and deliberately introduced into East Asia (EA) in the late 20th century, respectively. Specifically, we ask: (1) what percentage of the suitable $A$. artemisiifolia area is also suitable for the two agents in EA, and (2) which part of the suitable $A$. artemisiifolia area in EA is likely to remain uncovered by these two agents, both under current and future climatic scenarios; and (3) which particular biotypes would be needed to fill in the yet uncovered part of the suitable $A$. artemisiifolia range in East Asia? For this, we simultaneously modelled the species distributions based on worldwide occurrences and important bioclimatic variables for the target invasive plant and its two biological control agents. Ordination techniques were used to explore climatic constraints of each species and to perform niche overlap and similarity tests with A. artemisiifolia between its native North American and introduced EA range. Our results show that $O$. communa has a larger overlap with the geographic range of $A$. artemisiifolia than $E$. strenuana, both under current $(40.3 \%$ vs. $21.6 \%$ for $O$. communa and $E$. strenuana, respectively) and future climatic scenarios (29.8\% vs. $20.3 \%$ for $O$. communa and $E$. strenuana, respectively). Importantly, climate change is expected to reduce the total geographic overlap of $A$. artemisiifolia by the two agents combined (42.9\% vs. $29.8 \%$ for current and future climate conditions, respectively), with a higher reduction by $O$. communa than by E. strenuana. Our analyses also identified for which abiotic conditions to select in order to develop climatically adapted strains for particular regions, where $A$. artemisiifolia is presently unlikely to be covered.

Key words: biological control; biological invasions; Epiblema strenuana; niche overlap; Ophraella communa; species distribution

外来入侵植物(指有意引入或无意传播到原产 地以外地区的植物) 是导致全球变化的重要驱动因 子之一，对生态系统和社会经济有着严重的影响 (Vilà et al, 2011)。因此, 外来入侵植物的防治对于生 态学家、保护生物学家和涉及自然资源管理的环境 工作者是一个巨大的挑战(Walker \& Steffen, 1997; Kettenring \& Adam, 2011)。经典的生物防治方法, 是篮选来自入侵植物原产地的专食性天敌, 以达到 控制植物多度的目的。由于该方法成本低，可持续 性强, 环境安全性高, 所以被认为是迄今为止控制 入侵植物最为成功的手段 (Müller-Schärer \& Schaffner, 2008; Winston et al, 2014; Seastedt, 2015)。

物种分布模型(species distribution models, SDMs) 是利用已知的物种分布位点数据与环境因子研究 物种与环境间的关系。环境因子是决定物种生存和 繁殖的重要因素之一, 通过物种分布模型可以完成 对物种潜在地理分布区的预测 (Guisan \& Zimmermann, 2000)。此外, 物种分布模型也是预测 物种分布对气候变化响应的主要方法(Peterson, 2011)。近几年, 物种分布模型越来越多地用于预测 在当前和未来气候背景下入侵植物的地理分布并 识别高危生境(Peterson, 2003)。此外, 物种分布模型
也可以有效地预测入侵植物分布区内生物防治昆 虫的最佳生存区域(Sun et al, 2017)。由于生物物理 学因素, 昆虫种群受气候因子的影响非常显著 (Hoelmer \& Kirk, 2005), 所以, 物种分布模型还能 够帮助我们识别出生物防治昆虫在原产地的最佳 采集地和在引入区域的最佳释放点(Mukherjee et al, 2011)。已有研究发现, 生物防治昆虫的引入区域与 原产地的气候越匹配, 它们就越容易在引入区域建 立种群并更加有效地控制入侵植物(Goolsby et al, 2005)。因排序技术能够直接在环境空间内比较物种 与环境因子之间的关系, 利用该技术可以从物种分 布位点数据推断相应的生物防治效果(Broennimann et al, 2012)。

全球气候变化会导致物种分布区迁移(IPCC, 2013), 从而对生态系统的资源动态产生显著的影 响。气候变化对入侵植物和生物防治天敌的地理分 布影响尤为显著 (Theoharides \& Dukes，2007; Walther et al, 2009)。气候因子对种间相互作用也有 巨大的影响，进而决定物种分布，因此对生物防治 方案实施的有效性起关键作用(Messenger \& Van den Bosch, 1971)。植物和节肢动物对气候变化的响 应可能会是截然不同的(Hannah et al, 2002; Gillson 
et al, 2013), 因此, 为了制定可持续的生物防治管理 措施, 了解未来气候变化对外来入侵植物与生物防 治天敌的影响是至关重要的。生物气候模型能够对 当前和未来的气候背景进行深入的考量, 这就为我 们提供了一个经济的途径来解决这一未知的难题。

豚草(Ambrosia artemisiifolia) 是一年生风媒传 粉、雌雄同株的草本植物, 原产北美和墨西哥。它 被无意地引入全球的多个地区，包括亚洲、南美洲、 大洋洲和欧洲。它的花粉具有致敏性, 其植株作为 杂草在农田中极难控制; 所以不管是在原产地还是 入侵地, 豚草都造成了极大的危害(Wan et al, 2005; Essl et al, 2015)。中国的豚草分布区域内, 2-3\%的人 对其花粉有过敏症状, 这也直接导致了每年14亿元 人民币的损失(Zhou et al, 2015)。豚草入侵日本已经 超过100年(Fukano \& Yahara, 2012)。20世纪30年代, 在中国首次发现了豚草的分布记录, 直至1997年才 被认为是有害于多种农作物的杂草(Wan et al, 1993)。在中国(Wan et al，1993)和日本(Hisauchi, 1950), 豚草除了分布在农田以外, 还广泛地分布在 交通运输线上(比如铁路、公路和河流沿线)。豚草 经过收割和除草剂局部控制以后, 其侧枝的生长能 力非常强, 植株的生长速度也非常快, 这对管理和 控制是一个极大的挑战(Wan et al, 2005; Essl et al, 2015)。在农田中，除草剂对豚草生物量的控制是有 效的, 但是没法有效地遏制其开花、传粉和结果 (Gerber et al, 2011)。

经典的生物防治手段是可持续控制豚草的最 佳策略。在中国, 利用豚草原产地的生物天敌豚草 条纹叶甲 (Ophraella communa) 和豚草卷蛾 (Epiblema strenuana) 对豚草进行生物防治已经被证 明是最有效的方式(Zhou et al, 2011b)。两种天敌昆 虫都原产北美。豚草条纹叶甲是一种偏爱豚草作为 寄主植物和食物来源的寡食性叶甲(LeSage, 1986;

Futuyma \& McCafferty, 1990; Palmer \& Goeden, 1991)。在东亚地区, 于1996年在日本东部的千叶县 首次被发现(偶然引入), 此后迅速扩散到日本全境 (Yamazaki et al, 2000; Moriya \& Shiyake, 2001)。 1999年，豚草条纹叶甲第一次在中国发现(Zhou et al, 2014)。良好的环境条件下, 豚草条纹叶甲每年可以 繁殖4-7代, 这使它能够在豚草生长季的后半段形 成局部高密度种群。不论是在实验条件还是野外条 件下, 这种叶甲都能够导致豚草的叶片完全脱落和
死亡(Palmer \& Goeden, 1991; Zhou et al, 2014)。在中 国和日本, 豚草条纹叶甲均被认为是目前控制豚草 最有效、最成功的生物防治手段(Yamazaki et al, 2000; Fukano \& Doi, 2013)。豚草条纹叶甲主要分布 在亚热带地区(Zhou et al, 2010)。近几年，中国学者 尝试选出一些优良的豚草条纹叶甲品种, 使它们能 够在高纬度地区生存并繁殖后代(Zhou et al, 2011a, 2013)。但截至目前, 日本和韩国还没有进行人为释 放豚草条纹叶甲来防治豚草的实验(Winston et al, 2014)。

豚草卷蛾是一种采食植物茎部、由虫曒孵化而 来的蛾类。它将纺锤形虫瘞产于成熟豚草属植物的 侧枝上，适宜条件下每年能够繁殖3-4个世代(Ma et al, 2008)。在中国的华北地区一年可繁衍2-3个世代, 华中地区4-5个世代(Zhou et al, 2014)。1982年, 豚 草卷蛾被从墨西哥引入到澳大利亚来控制银胶菊 (Parthenium hysterophorus), 但是随后它广泛分布 在豚草植株上(McFadyen, 1992)。1990年, 我国从澳 大利亚引入豚草卷蛾来控制豚草, 经过宿主专一性 检测后, 于1993年释放到野外, 随后豚草卷蛾广泛 地分布于华南地区(Wan et al, 2005)。

1993年, 两种专食性生物防治昆虫在湖南岳阳 第一次大规模释放。1999年, 在湖南已控制了超过 $2,000 \mathrm{~km}^{2}$ 的豚草分布区。随后, 这两种专食性天敌 扩散到湖北省和江西省(Li et al, 1999)。在华南地区, 豚草条纹叶甲和豚草卷蛾共存于许多豚草分布区， 并被建议同时使用以更有效地控制豚草入侵(Zhou et al, 2014)。

基于豚草及其潜在生物防治天敌昆虫的全球 分布记录和重要的生物气候变量, Sun等(2017)利用 物种分布模型同时预测了豚草及其6种潜在生物防 治天敌的分布, 由此评估这些天敌在欧洲豚草分布 区域内的适应性顺序。本研究的主要目的是在当前 和未来气候条件下, 预测东亚地区豚草及其两种生 物防治天敌分布的重叠区域。具体包括以下 4 个方 面: (1)在豚草的适宜生长分布区内, 有多少区域也 同样适宜其两种天敌的生存? (2)有哪些区域适宜 豚草生存但是不适宜它的两种天敌生存? (3)哪些 气候因子有助于我们为特殊区域(适宜豚草生长却 不适宜两种昆虫天敌生长的区域)篮选出气候上的 适应性株系? (4)利用主成分分析, 对豚草和它的两 种专食性天敌在北美和东亚地区的气候生态位进 
行对比分析。

\section{1 材料与方法}

\section{1 物种分布记录和生物气候数据}

我们通过文献资料收集全球范围内所有可用 的豚草及其两种专食性天敌(豚草条纹叶甲和豚草 卷蛾)的分布记录。3个物种分布点的地理坐标信息 主要从以下 4 个网络资源中下载获得: (1) the Global Biodiversity Information Facility Online Database (GBIF; http://www.gbif.org); (2) the Southwest Environmental Information Network (SEINet; http://swbiodiversity.org); (3) the Barcode of Life Data Systems (BOLD; http://www.boldsystems.org/); (4) the Berkeley Ecoinformatics Engine (Ecoengine; https://ecoengine.berkeley.edu/)。更多分布数据可见 于Sun等(2017)文章的附录信息。

本研究使用了世界气候数据库中空间分辨率 为 5'弧分的 19 个气候数据 (Bio1-Bio19), (http://www.worldclim.org, Hijmans et al, 2005) (附 录1)。参考Sun等(2017), 在当前和4个未来气候背景 下, 我们为每个物种篮选出对其生存和发育的生理 功能起着重要作用的气候变量。对于未来2050年 (2041-2060的平均值)的气候情景, 我们采用了两种 一般循环模型(general circulation models (GCMs): HadGEM2-AO 和 IPSL-CM5A-LR), 以及两种典型 的二氧化碳浓度情境(RCP26和RCP85), 共4个未来 气候情景(Giorgetta et al, 2013)。数据开发于耦合模 型(Coupled Model Intercomparison Project Phase 5, CMIP5, IPCC Fifth Assessment) (IPCC, 2013), 下载 于http://www.worldclim.org, 空间分辨率为5, 弧分。 对于 4 个未来气候情景, 即HadGEM2-AO, RCP26 (HD-26); HadGEM2-AO, RCP85 (HD-85); IPSLCM5A-LR, RCP26 (IP-26); IPSL-CM5A-LR, RCP85 (IP-85), 我们使用相同的19个气候因子(附录1)。

\section{2 物种分布模型}

研究基于豚草、豚草条纹叶甲和豚草卷蛾的全 球分布记录及重要生物气候变量, 使用Biomod2 (Thuiller et al，2013)预测了当前和未来(4种气候变 化情景)气候条件下豚草及其生物防治昆虫在东亚 地区的分布。通过不同模型的组合调整预测内在的 不确定性, 并整合出一种最佳的模拟方案(Araújo \&
New, 2007)。本研究中, 我们综合运用了以下4种模 型：一般线性模型 (generalized linear models, GLM)、广义助推模型(generalized boosting models, GBM)、随机森林模型(random forest moldel, RF)和 最大熵模型(maximum entropy, MaxEnt)。模拟过程 中随机选取 $80 \%$ 的原始数据用于建模, $20 \%$ 的数据 用于模型验证。受试者工作特征曲线(ROC)和真实 技巧统计法(true skill statistic, TSS)来评估模型的预 测精度(Pearce \& Ferrier, 2000)。详情请见Sun等 (2017)。在未来气候情景下, 物种分布地图使用4种 未来气候预测的平均值和标准差。最后, 基于当前 气候情景下的二进制分布地图和4种未来气候情景 下的平均值二进制地图, 生成了两种生物防治昆虫 与豚草分布区的重叠区域。

\section{3 生物气候生态位分析}

使用 $\mathrm{R}$ 软件中ecospat包的排序技术比较了北美 原产地和东亚入侵地的豚草生态位(Broennimann et al, 2014)。基于豚草分布模型篮选出的9个生物气候 变量矩阵, 利用PCA-env的前两个主成分坐标轴对 生态位进行量化。在生态位重叠变量的排序中, ecospat已经被证实明显优于其他排序方法(Broennimann et al, 2012; Cola et al, 2016)。因此, 我们用 Ecospat中的PCA-env来检测生态位的等价性和相似 性。对两个区域的分布记录进行随机分配后，可以 通过等价性检验(niche equivalency)来计算其生态位 重叠区域是否恒定。生态位相似性(niche similarity) 检验了两个地区的生态位重叠区域是否高于其中 一个地区生态位与从另一个区域随机选择的生态 位之间的重叠区域。该检验同时从北美到东亚和从东 亚到北美的两个方向上进行(Broennimann et al, 2012)。 生态位等价性和相似性检验均使用100次重复。

所有模型使用 R-3.3.2 统计软件进行分析 ( $R$ Development Core Team, 2016)。

\section{2 结果}

\section{1 模型性能}

对所有 3 个物种和 4 种模型进行的预测能力评 价中, 曲线下面积 (AUC) 对模拟预测的辨别率在 0.70-0.99之间。95\%以上的AUC值大于 0.8 (AUC为 0.8 意味着所预测的适合生存的分布点有 $80 \%$ 的可 能性高于该点无分布记录的情况) (Wisz et al, 2008) 
(表1)。在所有的预测中, GBM和RF的预测能力持平, 并且其预测性能都优于 GLM和MaxEnt; 与豚草卷 蛾相比, 豚草和豚草条纹叶甲的AUC值更高(附录 2 )。总之, 在所有的模拟分析中我们都取得了较高 的AUC值。由此推断本研究的物种分布模型对 3 种 研究物种的气候适宜性的模拟预测是合理的。物种 分布模型的高精准预测显示 3 个物种的潜在分布区 与观测到的分布范围非常相近。同时, 高AUC值说 明利用全球的分布数据(即在原产地和其他引种地 区)来预测一个物种在入侵地区的分布图是可以获 得合理结果的。

表14种模型预测的当前和未来气候情景下的AUC值, 显 示可接受的AUC分数

Table 1 AUC power of all species using four models under current and future climate scenarios showing acceptable AUC scores

\begin{tabular}{|c|c|c|c|}
\hline & $\begin{array}{l}\text { Ambrosia ar- } \\
\text { temisiifolia }\end{array}$ & $\begin{array}{l}\text { Ophraella } \\
\text { communa }\end{array}$ & $\begin{array}{l}\text { Epiblema } \\
\text { strenuana }\end{array}$ \\
\hline \multicolumn{4}{|c|}{ 当前气候背景 Current climate scenario } \\
\hline 一般线性模型 GLM & $0.88 \pm 0.002$ & $0.88 \pm 0.004$ & $0.84 \pm 0.01$ \\
\hline 广义助推模型 GBM & $0.89 \pm 0.002$ & $0.90 \pm 0.003$ & $0.89 \pm 0.006$ \\
\hline 随机森林模型 RF & $0.89 \pm 0.003$ & $0.91 \pm 0.003$ & $0.89 \pm 0.006$ \\
\hline 最大熵模型 MaxEnt & $0.87 \pm 0.003$ & $0.83 \pm 0.004$ & $0.83 \pm 0.009$ \\
\hline \multicolumn{4}{|c|}{ 未来气候背景: HD-26 Future climate scenario: HD-26 } \\
\hline 一般线性模型 GLM & $0.87 \pm 0.003$ & $0.87 \pm 0.002$ & $0.83 \pm 0.01$ \\
\hline 广义助推模型 GBM & $0.89 \pm 0.002$ & $0.90 \pm 0.002$ & $0.90 \pm 0.006$ \\
\hline 随机森林模型 RF & $0.90 \pm 0.002$ & $0.91 \pm 0.002$ & $0.91 \pm 0.006$ \\
\hline 最大熵模型 MaxEnt & $0.86 \pm 0.003$ & $0.83 \pm 0.003$ & $0.80 \pm 0.01$ \\
\hline \multicolumn{4}{|c|}{ 未来气候背景: HD-85 Future climate scenario: HD-85 } \\
\hline 一般线性模型 GLM & $0.88 \pm 0.003$ & $0.88 \pm 0.002$ & $0.84 \pm 0.008$ \\
\hline 广义助推模型 GBM & $0.90 \pm 0.003$ & $0.92 \pm 0.001$ & $0.86 \pm 0.008$ \\
\hline 随机森林模型 RF & $0.89 \pm 0.003$ & $0.92 \pm 0.001$ & $0.86 \pm 0.009$ \\
\hline 最大熵模型 MaxEnt & $0.88 \pm 0.003$ & $0.84 \pm 0.003$ & $0.78 \pm 0.01$ \\
\hline \multicolumn{4}{|c|}{ 未来气候背景: IP-26 Future climate scenario: IP-26 } \\
\hline 一般线性模型 GLM & $0.89 \pm 0.003$ & $0.87 \pm 0.002$ & $0.87 \pm 0.01$ \\
\hline 广义助推模型 GBM & $0.90 \pm 0.002$ & $0.90 \pm 0.002$ & $0.91 \pm 0.008$ \\
\hline 随机森林模型 RF & $0.91 \pm 0.002$ & $0.91 \pm 0.001$ & $0.91 \pm 0.008$ \\
\hline 最大熵模型 MaxEnt & $0.89 \pm 0.003$ & $0.85 \pm 0.002$ & $0.82 \pm 0.009$ \\
\hline \multicolumn{4}{|c|}{ 未来气候背景: IP-85 Future climate scenario: IP-85 } \\
\hline 一般线性模型 GLM & $0.87 \pm 0.003$ & $0.87 \pm 0.002$ & $0.88 \pm 0.008$ \\
\hline 广义助推模型 GBM & $0.89 \pm 0.003$ & $0.90 \pm 0.002$ & $0.91 \pm 0.006$ \\
\hline 随机森林模型 RF & $0.91 \pm 0.003$ & $0.91 \pm 0.002$ & $0.91 \pm 0.006$ \\
\hline 最大熵模型 MaxEnt & $0.87 \pm 0.003$ & $0.84 \pm 0.003$ & $0.88 \pm 0.008$ \\
\hline
\end{tabular}

GLM, generalized linear model; GBM, generalized boosting model; R, random forest moldel; MaxEnt, maximum entropy.

\section{2 豚草和两种天敌昆虫适宜分布区的地理重叠}

豚草引入东亚地区已有近 100 年历史, 在此期 间，它的分布范围已经覆盖了从中国的东北到东南 地区、朝鲜半岛和日本的大部分地区(附录3)。这完 全符合它在原产地北美地区的纬度范围(Sun et al, 2017)。在未来气候变化背景下, 预测豚草分布范围 将向中国的西南地区以及更东北的地区扩张; 然而 在朝鲜半岛和日本变化微乎其微, 仅为 $2 \%$ (图1)。

基于对当前气候和未来4种气候情景下的模拟 预测, 我们发现在东亚地区豚草的适宜生长区内, 豚草条纹叶甲的分布面积要比豚草卷蛾的大, 并且 它在华南和日本分布更为广泛(图1)。与当前气候背 景下的物种分布区相比, 在未来气候背景下两种生 物防治昆虫的适宜分布区与豚草适宜分布区的重 叠区域明显减少, 其中豚草条纹叶甲减少得尤为明 显。豚草条纹叶甲与豚草适宜分布区的重叠区域从 40.3\% 降至 $29.8 \%$; 豚草卷蛾与豚草适宜分布区的 重叠区域从 $21.6 \%$ 降至 $20.3 \%$ 。在气候变化的背景下, 中国的西部和南部(尤其是重庆、贵州、广西、广东 和福建省)将不再适合豚草条纹叶甲的生存。另外, 我们预测中国的四川、河南、安徽、江苏以及日本 也将不适合豚草卷蛾的生存(图1)。在当前的气候情 况下, 豚草与两种专食性天敌昆虫的气候重叠区域 占到整个豚草分布区的 $42.9 \%$; 然而, 在未来的气 候情景下, 我们预测这一比例将下降至 $29.9 \%$ (附录 4)。当前气候和未来气候情景下, 3 个物种的适宜分 布区的预测展示于附录 4 和附录 5 。

\section{3 生物气候生态位分析}

我们用PCA-env对豚草在北美分布区的生态位 和东亚分布区的生态位进行了分析比较。第一和第 二主成分解释了数据变量的 $86.9 \%(\mathrm{PC} 1=74.28 \%$, $\mathrm{PC} 2=12.62 \%)($ 图2)。与原产地北美的生态位相比, 入侵地东亚地区的生态位显示出了大量的未饱和 区域。在东亚地区, 豚草将向着夏季更加凉爽和温 度季节性更强的区域扩散(图2A-C)。另外, 图2B显 示, 在东亚地区也小部分向最干月份降雨量减少的 区域转移的生态位。东亚地区和北美地区的生态位 等价性和两种方向的相似性并不显著 $(P>0.09)$ 。这 表明, 豚草在东亚地区的入侵过程中, 其环境生态 位经历了重大的转变(图2D-F)。在北美地区, 两种 昆虫天敌与豚草的生态位基本上完全重叠, 但是在 

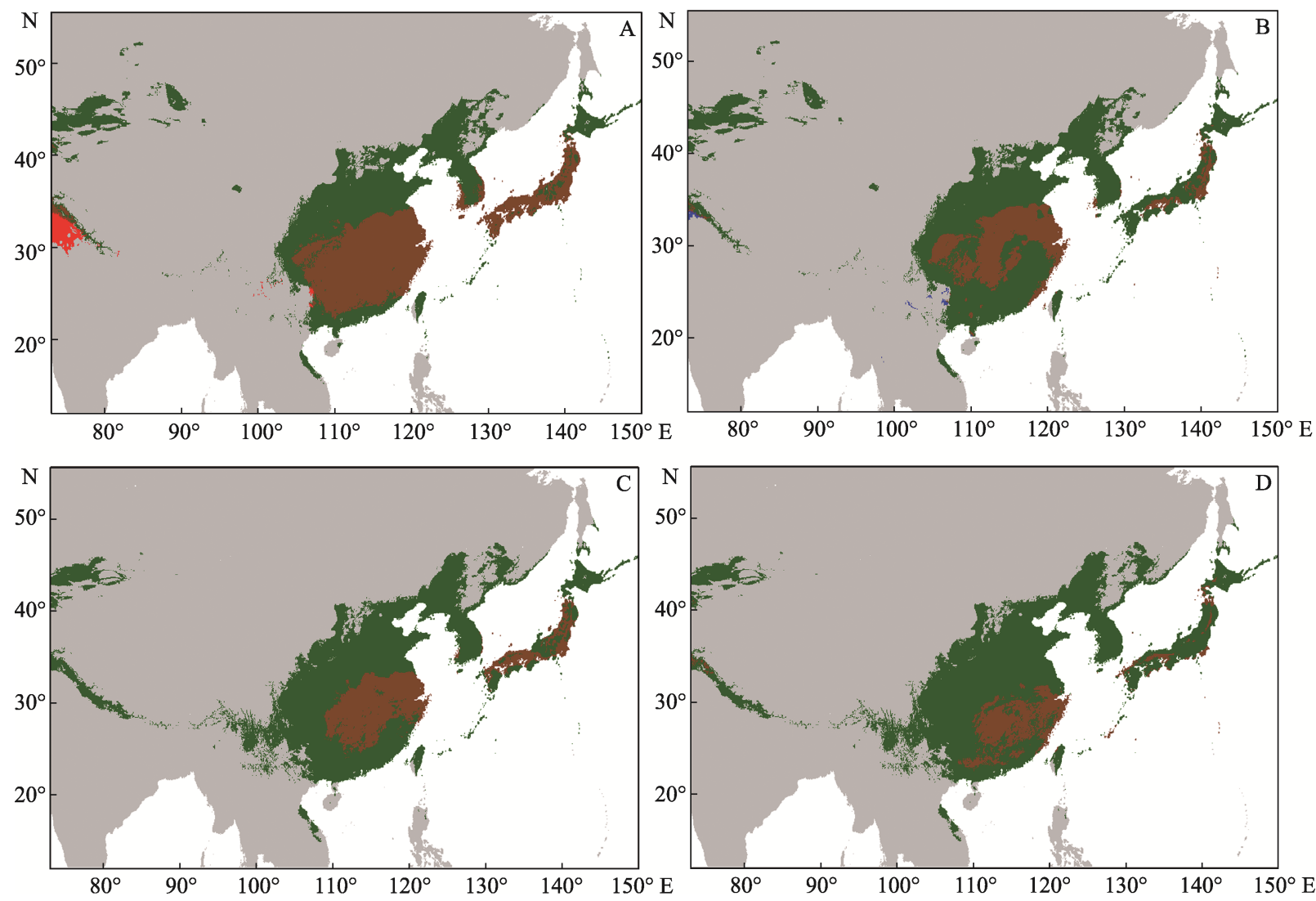

图1 在当前和未来气候情景下, 东亚地区的豚草与其两种专食性天敌的地理分布预测。气候适宜度代表每个物种最佳适宜 度阈值百分比。所有图中的深绿色代表的是豚草适宜分布区。在当前气候背景下: (A)红色为豚草条纹叶甲分布区, 褐色为豚 草条纹叶甲与豚草适宜分布区的重叠区域，占豚草适宜分布区的 $40.3 \% ;(B)$ 蓝色为豚草卷蛾分布区, 褐色为豚草卷蛾与豚草 适宜分布区的重叠区域，占豚草适宜分布区的 $21.6 \%$ 。未来气候条件下: (C)红色为豚草条纹叶甲分布区, 褐色为豚草条纹叶 甲与豚草适宜分布区的重叠区域，占豚草适宜分布区的 $29.8 \%$; (D)蓝色为豚草卷蛾分布区, 褐色为豚草卷蛾与豚草适宜分布 区的重叠区域，占豚草适宜分布区的 $20.3 \%$ 。模型的模拟是基于东亚地区进行的。

Fig. 1 Geographical predictions of Ambrosia artemisiifolia and two biological control insects for East Asia, under present and future climatic scenarios. The climatic suitability indicates the optimal threshold of the percentage of models predicting each species. Dark green in all figures, A. artemisiifolia; under current climatic conditions: (A) Red, Ophraella communa; sienna, overlap 40.3\%; (B) Blue, Epiblema strenuana; sienna, overlap 21.6\%; under future climatic scenarios: (C) Red, Ophraella communa; sienna, overlap 29.8\%; (D) Blue, Epiblema strenuana; sienna, overlap 20.3\%. Models calibrated in East Asia only.

东亚地区的寒冷和干旱区域, 两种昆虫天敌并未覆 盖豚草的生态位(图 2A, B)。

\section{3 讨论}

为了预测全球气候变化对东亚地区豚草生物防 治的影响, 我们同时模拟了当前和未来的气候条件。

\section{1 物种分布预测}

在东亚地区，豚草的生态位正在逐渐向更冷和 温度季节性更强的地区入侵, 这进一步证明了 Petitpierre等(2012)和Sun等(2017)之前对豚草在欧 洲的入侵区域预测。预测分布地图也显示, 目前东 亚地区豚草的适宜分布区有超过半数地区不适合
它的两种专食性昆虫天敌生存, 这显著低于北美地 区的比例。在北美地区，两种专食性天敌能够覆盖 $70 \%$ 的豚草适宜生长区(Sun et al, 2017)。在东亚地 区，这些未覆盖的区域主要位于中国华北地区、华 中地区，韩国大部分和日本北部地区(图1)。对于韩 国的超低适宜性预测可能是由于韩国可用于模型 预测的观察分布点记录较少。东亚地区的实际生态 位显示, 两种昆虫天敌没有覆盖的生态位主要是在 比较寒冷、干旱、温度季节性更高的区域, 这与我 们的地理预测非常吻合。

尽管各物种对 4 种假设气候变化响应不一, 4 种 未来生物气候情景的平均值还是很好地预测了豚 

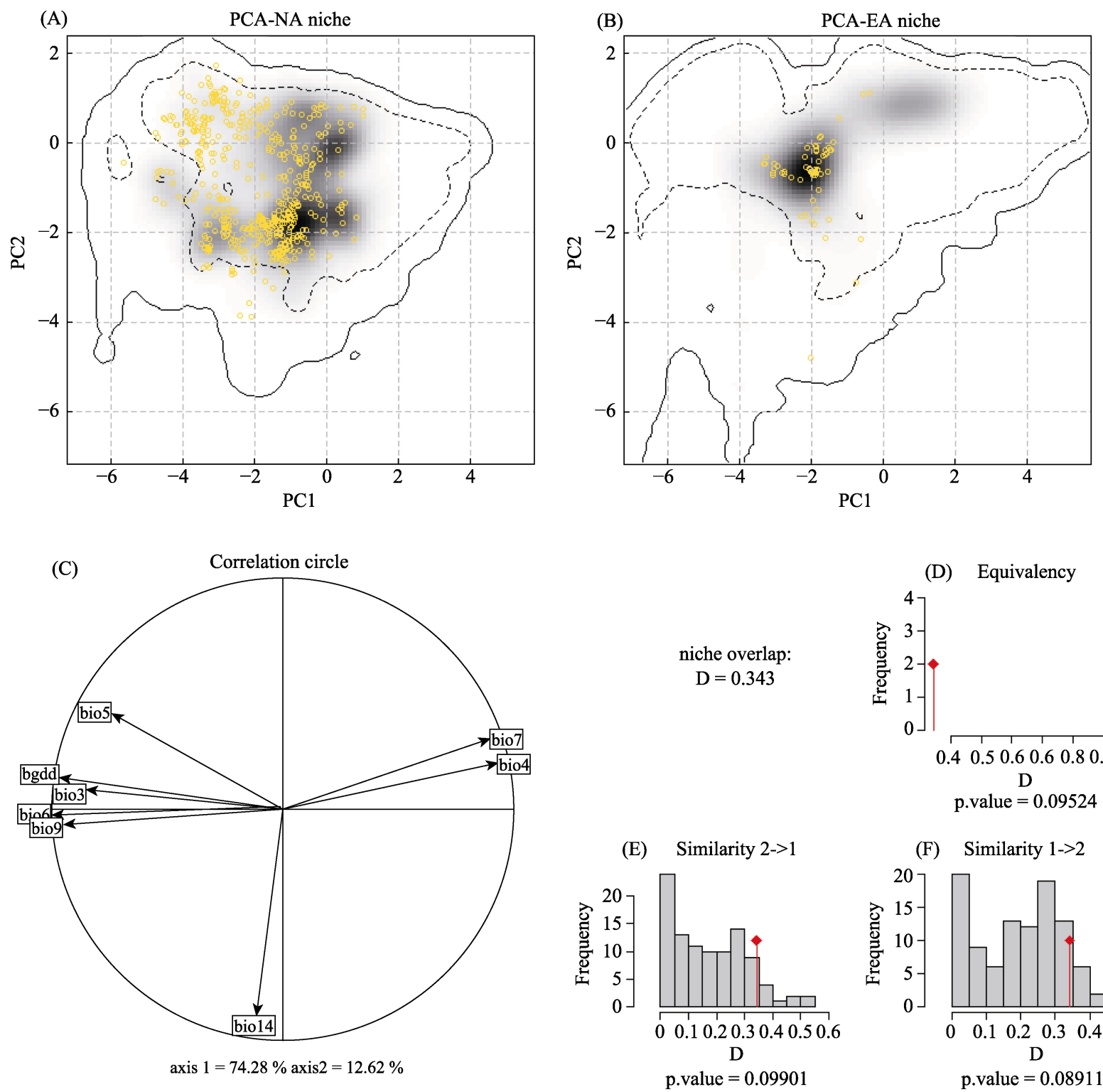

(D) Equivalency

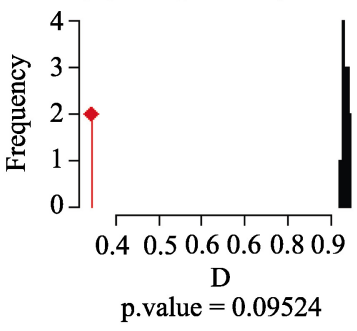

(F) Similarity 1->2

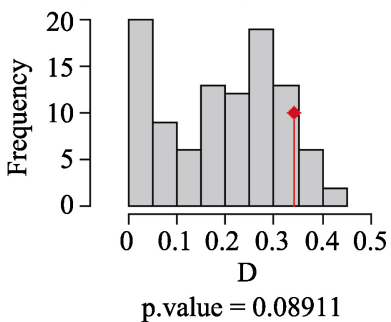

图2 对豚草生态位在气候空间的主成分分析结果。A图和B图分别代表豚草在原产地北美和入侵地东亚地区的生态位，沿主 成分 1 和主成分 2 的坐标图。灰色阴影显示物种在网格上分布记录的密度。实线的轮廓线表明 $100 \%$ 的背景环境, 虚线轮廓表 明最常见的 $50 \%$ 的背景环境。A图和B图中的黄色圆圈分别代表北美和东亚地区两种天敌的分布记录。C图表示的是气候变 量对主成分的两个坐标轴的贡献值并给出两个坐标轴解释变量的百分比。D-F的柱形图表示北美和东亚两个区域内观察到的 生态位重叠(线条和菱形)。(D)东亚和北美地区生态位等价性检验; (E)东亚到北美地区的生态位相似性; (F)北美到东亚的生态 位相似性。

Fig. 2 Niche of Ambrosia artemisiifolia in climatic space using principal component analysis (PCA-env). Panels (A) and (B) represent the niche of the species along the two first axes of the PCA for the native North American (NA) and introduced East Asian (EA) range, respectively. Gray shading shows the density of the occurrences of the species by the cell. The solid contour lines illustrate $100 \%$ of the available environment, and dashed lines indicate the $50 \%$ of the most common background environment. Yellow circles in (A) and (B) give the occurrences of two insect species in NA and in EA. The contribution of the climatic variables of the two axes of the PCA and the percentage of inertia explained by the two axes is given in (C). Histograms (D-F) show the observed niche overlap between the two ranges (bars and a diamond) and simulated niche overlaps (gray bars) on which tests of niche equivalency (D), niche similarity of EA and NA (E), and niche similarity of NA and EA (F) are calculated from 100 iterations, with the significance level of the tests.

草及其生物防治天敌在东亚分布的重叠区域。气候 变化将会使重叠部分进一步减少(当前气候对未来
气候情景的重叠比例为 $42.9 \%$ vs. $29.8 \%)$ 。尤其是豚 草条纹叶甲与豚草适宜生存区的空间重叠区域占 
豚草适宜生存区的比例从 $40.3 \%$ 下降至 $29.8 \%$ 。该结 果与对欧洲两种物种分布的预测结果是一致的(Sun et al, 2017)。在未来气候变化的情况下, 东亚地区适 宜生物防治昆虫地理分布区减少的一个可能的原 因是: 未来夏天变得更加炎热, 晚秋的霜冻和温度 的季节性增强, 这些将导致豚草向北方和西方进一 步扩散, 但是它的两种专食性天敌却并非如此。这进 一步证明了入侵植物和它的生物防治天敌对气候变 化并不一定有着相似的反应(Schweiger et al, 2008; Barriopedro et al, 2011; Björkman \& Niemela, 2015)。

\section{2 管理启示}

在中国的西部和北部、韩国和日本北部的大部 分豚草分布区域将不再适合它的两种天敌的生存。 韩国不适合豚草条纹叶甲的生存; 同时, 豚草卷蛾 的适宜生存区也未覆盖到韩国和日本大部分地区。 我们可以通过以下两种方法来弥补这一空间覆盖 区域上的缺口: (1)探索、发现并引进其他的生物防 治天敌(见Gerber et al, 2011); (2)篎选出适应这一空 缺区域的豚草条纹叶甲和豚草卷蛾的株系。对此, 生态位分析清楚地表明气候因子可以为我们遴选 出适应这些区域的特殊的昆虫天敌株系(比如䇻选 适应于夏季温度更低和温度季节性增强的品种)。所 以, 与这些特殊气候适应性状相关的遗传变异显得 尤为重要。但是到目前为止, 针对生物防治昆虫的 这些功能性状遗传变异的研究仍然十分贵乏(Roderick et al, 2012)。近几年, 研究报道了豚草条纹叶 甲的一些相关性状的遗传变异, 如飞行行为(Tana$\mathrm{ka}, 2009$ )和光周期对环境条件的应答(Tanaka et al, 2015)。Zhou等(2013)已经通过低温驯化篎选出了一 些适应低温的豚草条纹叶甲株系, 并可能将它们应 用于华北地区的豚草生物防治当中。因此, 这一特 殊的生物防治天敌株系能够追踪它们的寄主植物 到更冷的区域, 并且通过增加世代的方式在这些区 域形成更高的种群密度。在大量的商业生产和投放 中利用特殊的选择机制可以加快特定天敌株系的 培育, 并更好地控制东亚生物防治天敌未覆盖的豚 草分布区。

豚草与其生物防治天敌的种群动态及其相互 作用对于未来准确预测其分布有着不可忽视的作 用。未来对这些方面的进一步研究能够提高物种分 布的预测准确度，从而进行更为成功的生物防治。
致谢：感谢University of Fribourg的宋以刚和复旦 大学的赵四方协助翻译本文。

\section{参考文献}

Araújo MB, New M (2007) Ensemble forecasting of species distributions. Trends in Ecology \& Evolution, 22, 42-47.

Barriopedro D, Fischer EM, Luterbacher J, Trigo RM, García-Herrera R (2011) The hot summer of 2010: redrawing the temperature record map of Europe. Science, 332, 220-224.

Björkman C, Niemelä P (2015) Climate Change and Insect Pests. CABI, Oxfordshire, UK.

Broennimann O, Fitzpatrick MC, Pearman PB, Petitpierre B, Pellissier L, Yoccoz NG, Thuiller W, Fortin MJ, Randin C, Zimmermann NE (2012) Measuring ecological niche overlap from occurrence and spatial environmental data. Global Ecology and Biogeography, 21, 481-497.

Broennimann O, Petitpierre B, Randin C, Engler R, Breiner F, Manuela D, Pellissier L, Pottier J, Pio D, Mateo RG (2014) Package 'ecospat'. https://cran.r-project.org/web/packages/ ecospat/index.html.

Cola VD, Broennimann O, Petitpierre B, Breiner FT, D'Amen M, Randin C, Engler R, Pottier J, Pio D, Dubuis A (2016) ecospat: an R package to support spatial analyses and modeling of species niches and distributions. Ecography, 40, 774-787.

Essl F, Biró K, Brandes D, Broennimann O, Bullock JM, Chapman DS, Chauvel B, Dullinger S, Fumanal B, Guisan A (2015) Biological flora of the British Isles: Ambrosia artemisiifolia. Journal of Ecology, 103, 1069-1098.

Fukano Y, Doi H (2013) Population abundance and host use pattern of Ophraella communa (Coleoptera: Chrysomelidae) in its native and introduced range. Biocontrol Science and Technology, 23, 595-601.

Fukano Y, Yahara T (2012) Changes in defense of an alien plant Ambrosia artemisiifolia before and after the invasion of a native specialist enemy Ophraella communa. PLoS ONE, 7, e49114.

Futuyma DJ, McCafferty SS (1990) Phylogeny and the evolution of host plant associations in the leaf beetle genus Ophraella (Coleoptera, Chrysomelidae). Evolution, 44, 1885-1913.

Gerber E, Schaffner U, Gassmann A, Hinz H, Seier M, Müller-Schärer H (2011) Prospects for biological control of Ambrosia artemisiifolia in Europe: learning from the past. Weed Research, 51, 559-573.

Gillson L, Dawson TP, Jack S, McGeoch MA (2013) Accommodating climate change contingencies in conservation strategy. Trends in Ecology and Evolution, 28, 135-142.

Giorgetta MA, Jungclaus J, Reick CH, Legutke S, Bader J, Böttinger M, Brovkin V, Crueger T, Esch M, Fieg K (2013) Climate and carbon cycle changes from 1850 to 2100 in MPI-ESM simulations for the Coupled Model Intercom- 
parison Project phase 5. Journal of Advances in Modeling Earth Systems, 5, 572-597.

Goolsby JA, De Barro PJ, Kirk AA, Sutherst RW, Canas L, Ciomperlik MA, Ellsworth PC, Gould JR, Hartley DM, Hoelmer KA (2005) Post-release evaluation of biological control of Bemisia tabaci biotype "B" in the USA and the development of predictive tools to guide introductions for other countries. Biological Control, 32, 70-77.

Guisan A, Zimmermann NE (2000) Predictive habitat distribution models in ecology. Ecological Modelling, 135, 147-186.

Hannah L, Midgley GF, Millar D (2002) Climate changeintegrated conservation strategies. Global Ecology and Biogeography, 11, 485-495.

Hijmans RJ, Cameron SE, Parra JL, Jones PG, Jarvis A (2005) Very high resolution interpolated climate surfaces for global land areas. International Journal of Climatology, 25, 19651978.

Hisauchi K (1950) Naturalized Plants. Kagakutosyo syuppan, Tokyo.

Hoelmer K, Kirk A (2005) Selecting arthropod biological control agents against arthropod pests: Can the science be improved to decrease the risk of releasing ineffective agents? Biological Control, 34, 255-264.

IPCC (2013) Climate change 2013: The Physical Science Basis.

Kettenring KM, Adams CR (2011) Lessons learned from invasive plant control experiments: a systematic review and meta-analysis. Journal of Applied Ecology, 48, 970-979.

LeSage L (1986) A taxonomic monograph of the Nearctic galerucine genus Ophraella Wilcox (Coleoptera: Chrysomelidae). Memoirs of the Entomological Society of Canada, 118, 3-75.

Li HK, Li M, Li D (1999) Ambrosia artemisiifolia and its biological control. World Agriculture, (8), 40-41. (in Chinese) [李宏科, 李萌, 李丹 (1999) 豚草及其防治概况. 世界农 业, (8), 40-41.]

Ma J, Guo JY, Wan FH, Hu X, Wan FH, Li B, Guo J (2008) Biological control of Ambrosia artemisiifolia and A. trifida. In: Biological Invasions: Biological Control Theory and Practice, pp. 157-185. Science Press, Beijing. (in Chinese with English abstract) [马骏, 郭建英, 万方浩 (2008) 普 通豚草和三裂叶豚的生物防治，见: 生物入侵: 生物防治 篇(万方浩, 李保平, 郭建英主编), 157-185页. 科学出版 社, 北京.]

McFadyen RC (1992) Biological control against Parthenium weed in Australia. Crop Protection, 11, 400-407.

Messenger P, van den Bosch R (1971) The adaptability of introduced biological control agents. In: Biological Control (ed. Huffaker CB), pp. 68-92. Springer, Boston.

Moriya S, Shiyake S (2001) Spreading the distribution of an exotic ragweed beetle, Ophraella communa LeSage (Coleoptera: Chrysomelidae), in Japan. Japanese Journal of Entomology (New Series), 4, 99-102.

Mukherjee A, Christman MC, Overholt WA, Cuda JP (2011) Prioritizing areas in the native range of hygrophila for sur- veys to collect biological control agents. Biological Control, 56, 254-262.

Müller-Schärer H, Schaffner U (2008) Classical biological control: exploiting enemy escape to manage plant invasions. Biological Invasions, 10, 859-874.

Palmer W, Goeden R (1991) The host range of Ophraella communa LeSage (Coleoptera: Chrysomelidae). The Coleopterists' Bulletin, 45, 115-120.

Pearce J, Ferrier S (2000) Evaluating the predictive performance of habitat models developed using logistic regression. Ecological Modelling, 133, 225-245.

Peterson AT (2003) Predicting the geography of species' invasions via ecological niche modeling. The Quarterly Review of Biology, 78, 419-433.

Peterson AT (2011) Ecological niches and geographic distributions (MPB-49). Princeton University Press, New Jursey.

Petitpierre B, Kueffer C, Broennimann O, Randin C, Daehler C, Guisan A (2012) Climatic niche shifts are rare among terrestrial plant invaders. Science, 335, 1344-1348.

R Core Team (2016) R: A language and environment for statistical computing. R Foundation for Statistical Computing, Vienna, Austria. http://www.R-project.org/.

Roderick GK, Hufbauer R, Navajas M (2012) Evolution and biological control. Evolutionary Applications, 5, 419-423.

Schweiger O, Settele J, Kudrna O, Klotz S, Kühn I (2008) Climate change can cause spatial mismatch of trophically interacting species. Ecology, 89, 3472-3479.

Seastedt TR (2015) Biological control of invasive plant species: a reassessment for the Anthropocene. New Phytologist, 205, 490-502.

Sun Y, Brönnimann O, Roderick GK, Poltavsky A, Lommen STE, Müller-Schärer H (2017) Climatic suitability ranking of candidate biological control agents for weeds: a biogeographic approach for ragweed management in Europe under present and future climatic conditions. Ecosphere, 8, e01731.

Tanaka K (2009) Genetic variation in flight activity of Ophraella communa (Coleoptera: Chrysomelidae): heritability estimated by artificial selection. Environmental Entomology, 38, 266-273.

Tanaka K, Murata K, Matsuura A (2015) Rapid evolution of an introduced insect Ophraella communa LeSage in new environments: temporal changes and geographical differences in photoperiodic response. Entomological Science, 18, 104-112.

Theoharides KA, Dukes JS (2007) Plant invasion across space and time: factors affecting nonindigenous species success during four stages of invasion. New Phytologist, 176, 256-273.

Thuiller W, Georges D, Engler R (2013) Biomod2: ensemble platform for species distribution modeling. $\mathrm{R}$ package. http://CRAN. R-project. org/package= biomod2.

Vilà M, Espinar JL, Hejda M, Hulme PE, Jarošík V, Maron JL, Pergl J, Schaffner U, Sun Y, Pyšek P (2011) Ecological impacts of invasive alien plants: a meta-analysis of their effects on species, communities and ecosystems. Ecology Letters, 
14, 702-708.

Walker B, Steffen W (1997) An overview of the implications of global change for natural and managed terrestrial ecosystems. Conservation Ecology, 1, 2.

Walther G-R, Roques A, Hulme PE, Sykes MT, Pyšek P, Kühn I, Zobel M, Bacher S, Botta-Dukát Z, Bugmann H (2009) Alien species in a warmer world: risks and opportunities. Trends in Ecology \& Evolution, 24, 686-693.

Wan FH, Liu WX, Ma J, Guo J (2005) Ambrosia artemisiifolia and A. trifida. In: Biology and Management of Invasive Alien Species in Agriculture and Forestry (eds Wan FH, Zheng XB, Guo JY), pp. 662-688. Science Press, Beijing. (in Chinese) [万方浩, 刘万学, 马骏, 郭建英 (2005) 普通豚草 和三裂叶豚草. 见: 重要农林外来入侵物种的生物学与 控制(万方浩, 郑小波, 郭建英主编), 662-688页. 科学出 版社, 北京.]

Wan FH, Guan GQ, Wang R (1993) Ambrosia and Its Comprehensive Administration. Chinese Science and Technology Press, Beijing. (in Chinese) [万方浩, 关广清, 王韧 (1993) 豚草及豚草综合治理. 中国科学技术出版社, 北 京.]

Winston RL, Schwarzländer M, Hinz HL, Day MD, Cock MJW, Julien MH (2014) Biological Control of Weeds: A World Catalogue of Agents and Their Target Weeds, 5th edn. USDA Forest Service, Forest Health Technology Enterprise Team, Virginia.

Wisz MS, Hijmans R, Li J, Peterson AT, Graham C, Guisan A (2008) Effects of sample size on the performance of species distribution models. Diversity and Distributions, 14, 763-773.

Yamazaki K, Imai C, Natuhara Y (2000) Rapid population growth and food-plant exploitation pattern in an exotic leaf beetle, Ophraella communa LeSage (Coleoptera: Chry- somelidae), in western Japan. Applied Entomology and Zoology, 35, 215-223.

Zhou ZS, Chen HS, Zheng XW, Guo JY, Guo W, Li M, Luo M, Wan FH (2014) Control of the invasive weed Ambrosia artemisiifolia with Ophraella communa and Epiblema strenuana. Biocontrol Science and Technology, 24, 950-964.

Zhou ZS, Guo JY, Chen HS, Wan FH (2010) Effects of temperature on survival, development, longevity, and fecundity of Ophraella communa (Coleoptera: Chrysomelidae), a potential biological control agent against Ambrosia artemisiifolia (Asterales: Asteraceae). Environmental Entomology, 39, 1021-1027.

Zhou ZS, Guo JY, Michaud JP, Li M, Wan FH (2011a) Variation in cold hardiness among geographic populations of the ragweed beetle, Ophraella communa LeSage (Coleoptera: Chrysomelidae), a biological control agent of Ambrosia artemisiifolia L. (Asterales: Asteraceae), in China. Biological Invasions, 13, 659-667.

Zhou ZS, Guo JY, Wan FH (2015) Review on management of Ambrosia artemisiifolia using natural enemy insects. Chinese Journal of Biological Control, 31, 657-665.

Zhou ZS, Guo JY, Zheng XW, Luo M, Chen HS, Wan FH (2011b) Reevaluation of biosecurity of Ophraella communa against sunflower (Helianthus annuus). Biocontrol Science and Technology, 21, 1147-1160.

Zhou ZS, Rasmann S, Li M, Guo JY, Chen HS, Wan FH (2013) Cold temperatures increase cold hardiness in the next generation Ophraella communa beetles. PLoS ONE, 8, e74760.

\section{(责任编委: 丁建清 责任编辑: 时意专)}

\section{附录 Supplementary Material}

附录1 WORLDCLIM的生物气候数据集的19个生物气候因子和生长有效积温

Appendix 1 List of all 19 predictors available in WORLDCLIM bioclimatic data set and growth degree days (GDD)

http://www.biodiversity-science.net/fileup/PDF/2017096-1.pdf

附录2 模型预测能力(AUC)的差异

Appendix 2 Differences in discrimination ability (AUC) across all levels

http://www.biodiversity-science.net/fileup/PDF/2017096-2.pdf

附录3 在当前气候情景下, 利用观察记录预测的东亚地区豚草和它的两种天敌的地理分布

Appendix 3 Geographic continence predictions of Ambrosia artemisiifolia and its two biological control agents, Ophraella communa and Epibleama strenuana under present climatic scenarios in East Asia with occurrences presented.

http://www.biodiversity-science.net/fileup/PDF/2017096-3.pdf

附录4 当前和未来气候情景下, 东亚地区豚草与其两种天敌的地理分布重叠区预测

Appendix 4 Geographic predictions of overlap of Ambrosia artemisiifolia and its two biological control agents Ophraella communa and Epiblema strenuana under present and future climatic scenarios in East Asia.

http://www.biodiversity-science.net/fileup/PDF/2017096-4.pdf

附录5 在未来气候情境下, 东亚地区豚草及两种天敌的地理分布预测的平均值和标准差

Appendix 5 Mean and standard deviation of geographic predictions of Ambrosia artemisiifolia and its two biological control agents Ophraella communa and Epiblema strenuana under four future climatic scenarios in East Asia.

http://www.biodiversity-science.net/fileup/PDF/2017096-5.pdf 